\title{
Confirmation of Suzuki-Miyaura Cross-coupling Reaction Mechanism through Synthetic Architecture of Nanocatalysts
}

Bo Sun ${ }^{1}$, Lulu Ning ${ }^{2}$, Hua Chun Zeng ${ }^{1, *}$

${ }^{1}$ Department of Chemical and Biomolecular Engineering, Faculty of Engineering, National University of Singapore, 10 Kent Ridge Crescent, Singapore 119260

${ }^{2}$ College of Bioresource Chemical and Materials Engineering, Shaanxi University of Science and Technology, Shaanxi, China 710021

*Email: chezhc@nus.edu.sg

Table of Contents

Supporting Figures:

Supporting Tables:

Calculated Molecular Dimensions:
Pages S-2 to S-27

Pages S-28 to S-29

Pages S-30 to S-32 


\section{Supporting Figures:}

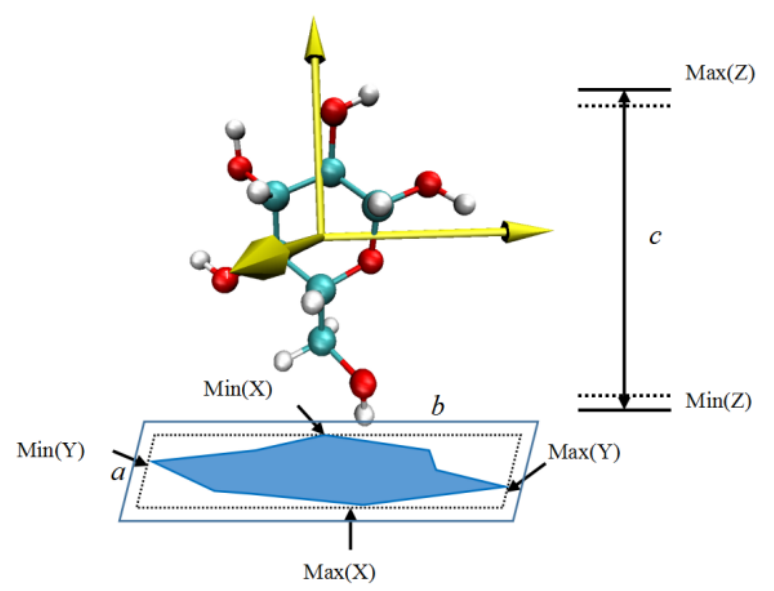

$a=\operatorname{Max}(X)-\operatorname{Min}(X)+\operatorname{Radius}(A 1)+\operatorname{Radius}(A 2)$

$b=\operatorname{Max}(Y)-\operatorname{Min}(Y)+\operatorname{Radius}(B 1)+\operatorname{Radius}(B 2)$

$c=\operatorname{Max}(Z)-\operatorname{Min}(Z)+\operatorname{Radius}(C 1)+\operatorname{Radius}(C 2)$

$A 1, A 2, B 1, B 2, C 1, C 2$ are boundary atoms

Figure S1. Illustration of the computational method.

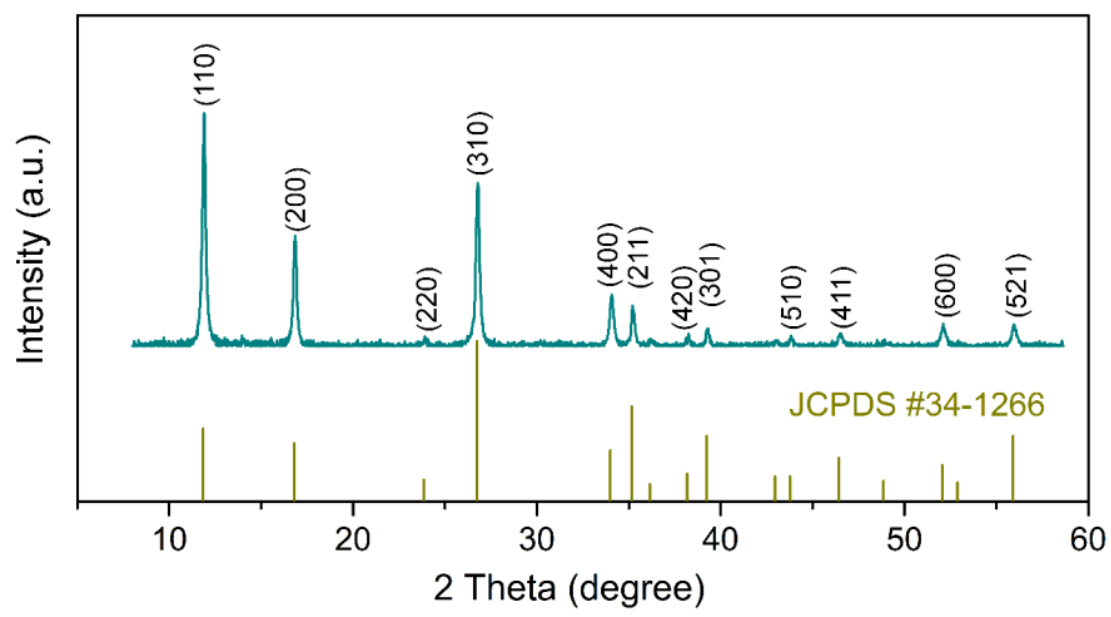

Figure S2. XRD pattern of $\beta-\mathrm{FeOOH}$ spindles. 

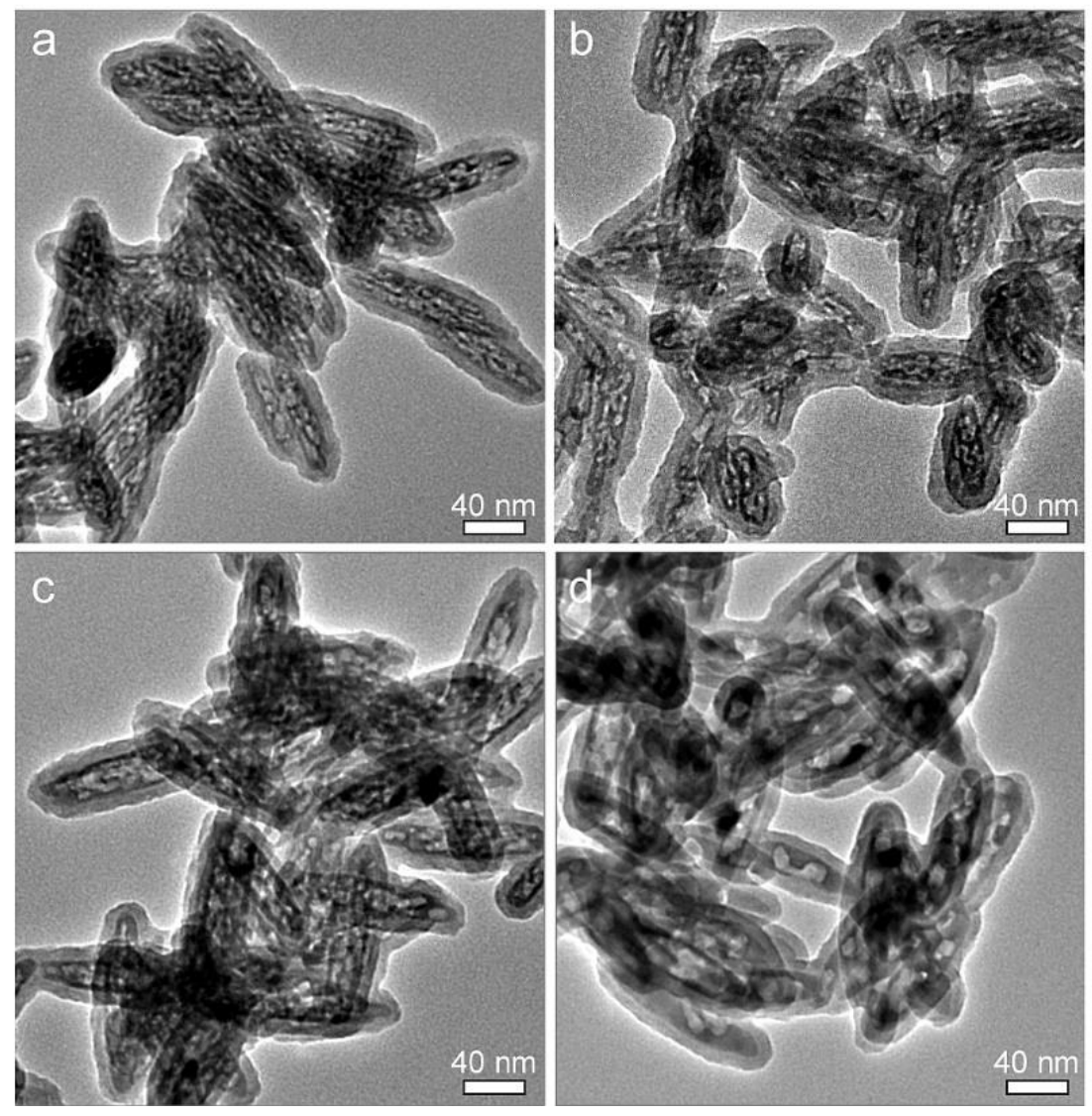

Figure S3. TEM images of $\mathrm{Pd} / \mathrm{FeO}_{\mathrm{x}} @ \mathrm{SiO}_{2}$ calcined at different temperatures: (a) $500^{\circ} \mathrm{C}$, (b) $600^{\circ} \mathrm{C}$, (c) $700^{\circ} \mathrm{C}$, and (d) $800^{\circ} \mathrm{C}$.

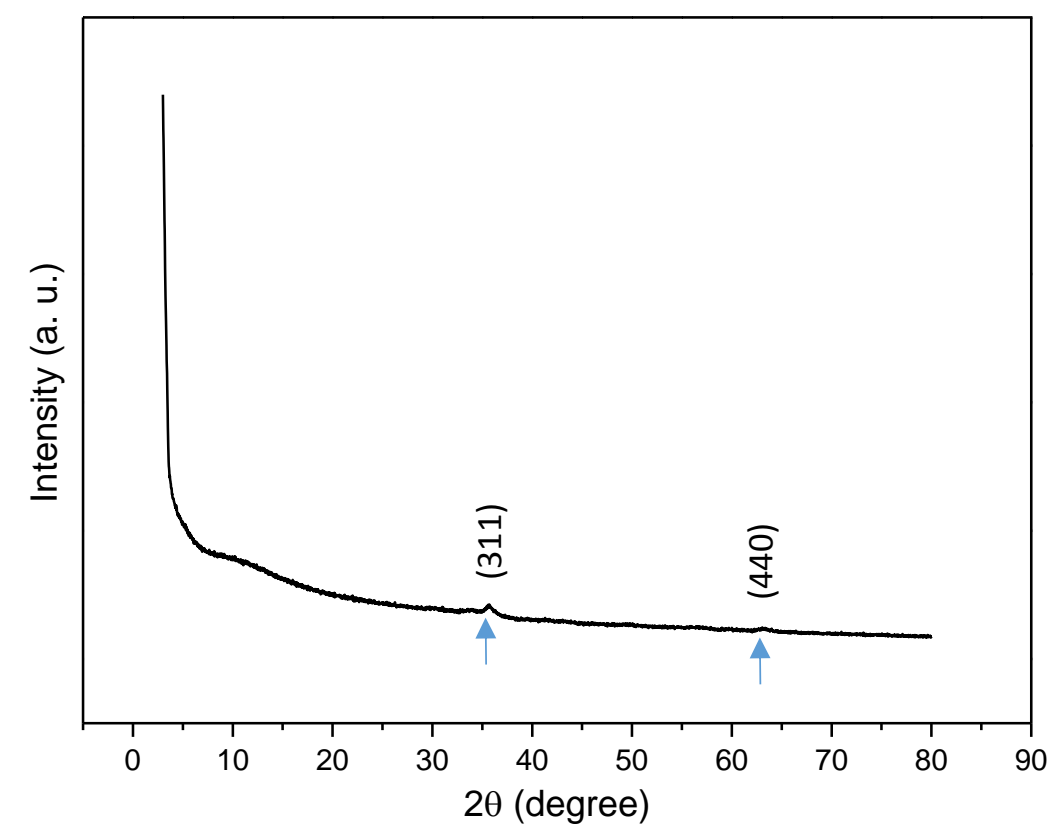

Figure S4. XRD pattern of $\mathrm{Pd} / \mathrm{FeO}_{\mathrm{x}} @ \mathrm{SiO}_{2}-600$. The $\mathrm{FeO}_{\mathrm{x}}$ phase is essentially amorphous. However, the tiny peaks marked with arrows can be assigned to (311) and (440) reflections of spinel oxide $\mathrm{Fe}_{3} \mathrm{O}_{4}$. 

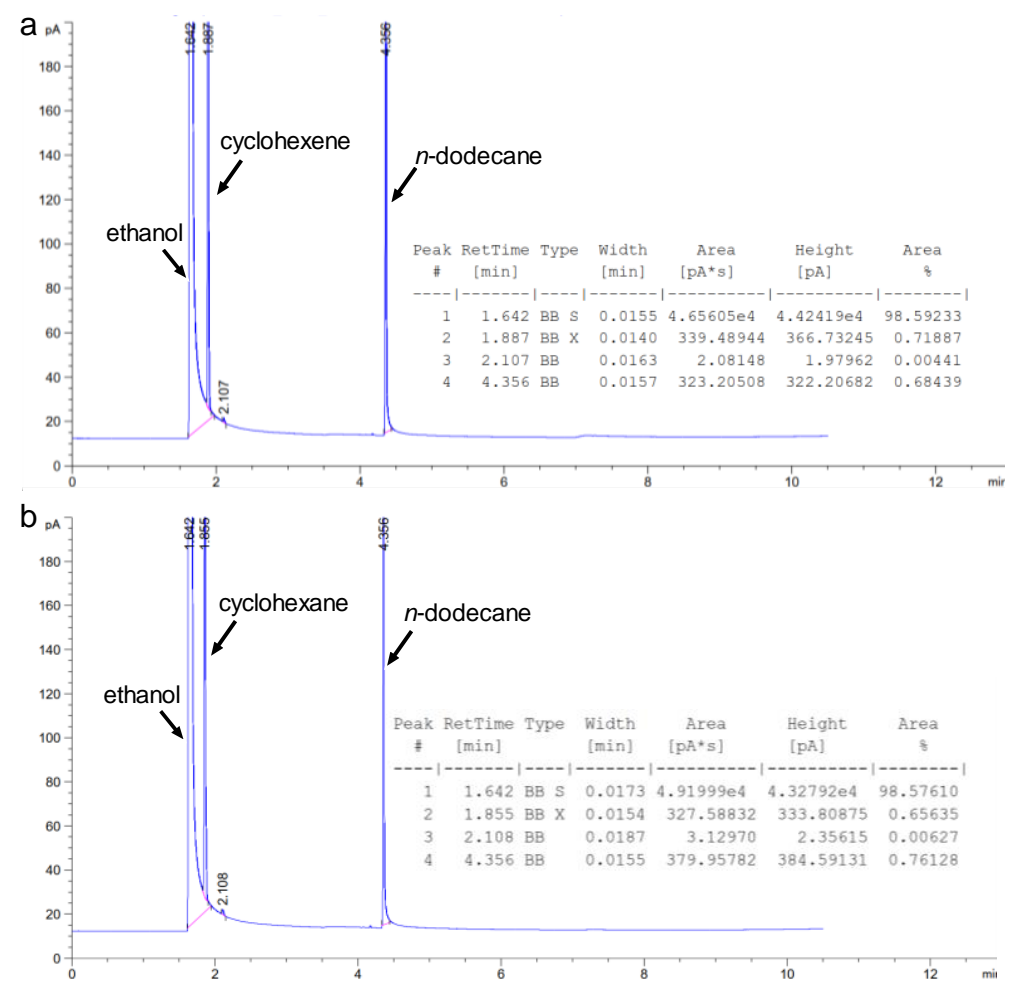

Figure S5. GC chromatograms of cyclohexene hydrogenation using $\mathrm{Pd} / \mathrm{FeO}_{\mathrm{x}} @ \mathrm{SiO}_{2}-600$ as catalyst: (a) before reaction (at time $=0$ ), and (b) after reaction (120 min). Reaction conditions: $1 \mathrm{mmol}$ of cyclohexene, $10 \mathrm{~mL}$ of ethanol, $0.1 \mathrm{~mL}$ of $n$-dodecane (as internal standard), $\mathrm{H}_{2}$ flow (30 $\mathrm{mL} \cdot \mathrm{min}^{-1}$ ), $120 \mathrm{~min}$ at room temperature and atmospheric pressure. $\mathrm{GC}$ operating conditions: inlet temperature at $250{ }^{\circ} \mathrm{C}$, FID temperature at $280{ }^{\circ} \mathrm{C}$, and oven at $70-280{ }^{\circ} \mathrm{C}$ with the ramp rate of $20^{\circ} \mathrm{C} / \mathrm{min}$.
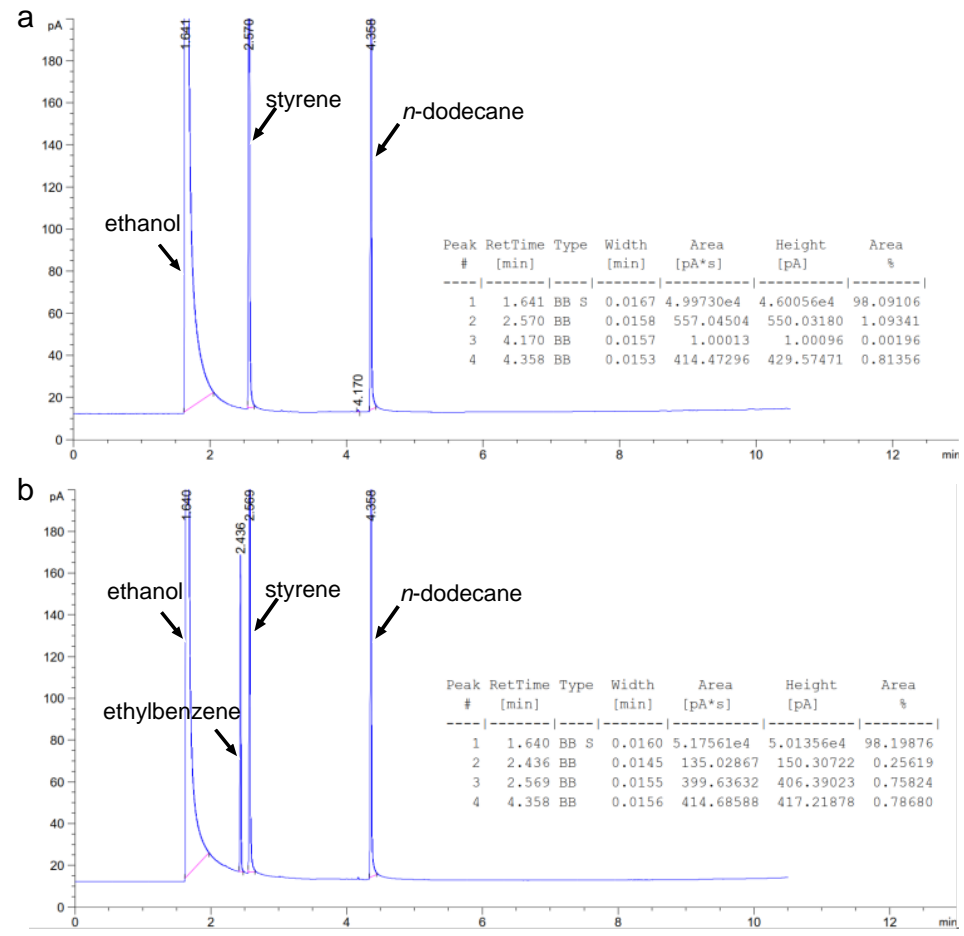
Figure S6. GC chromatograms of styrene hydrogenation using $\mathrm{Pd} / \mathrm{Fe} \mathrm{O}_{\mathrm{x}} @ \mathrm{SiO}_{2}-600$ as catalyst: (a) before reaction (at time $=0$ ), and (b) after reaction $(120 \mathrm{~min})$. Reaction conditions: $1 \mathrm{mmol}$ of styrene, $10 \mathrm{~mL}$ of ethanol, $0.1 \mathrm{~mL}$ of $n$-dodecane (as internal standard), $\mathrm{H}_{2}$ flow $\left(30 \mathrm{~mL} \cdot \mathrm{min}^{-1}\right), 120$ $\mathrm{min}$ at room temperature and atmospheric pressure. $\mathrm{GC}$ operating conditions: inlet temperature at $250{ }^{\circ} \mathrm{C}$, FID temperature at $280{ }^{\circ} \mathrm{C}$, and oven at $70-280{ }^{\circ} \mathrm{C}$ with the ramp rate of $20^{\circ} \mathrm{C} / \mathrm{min}$.
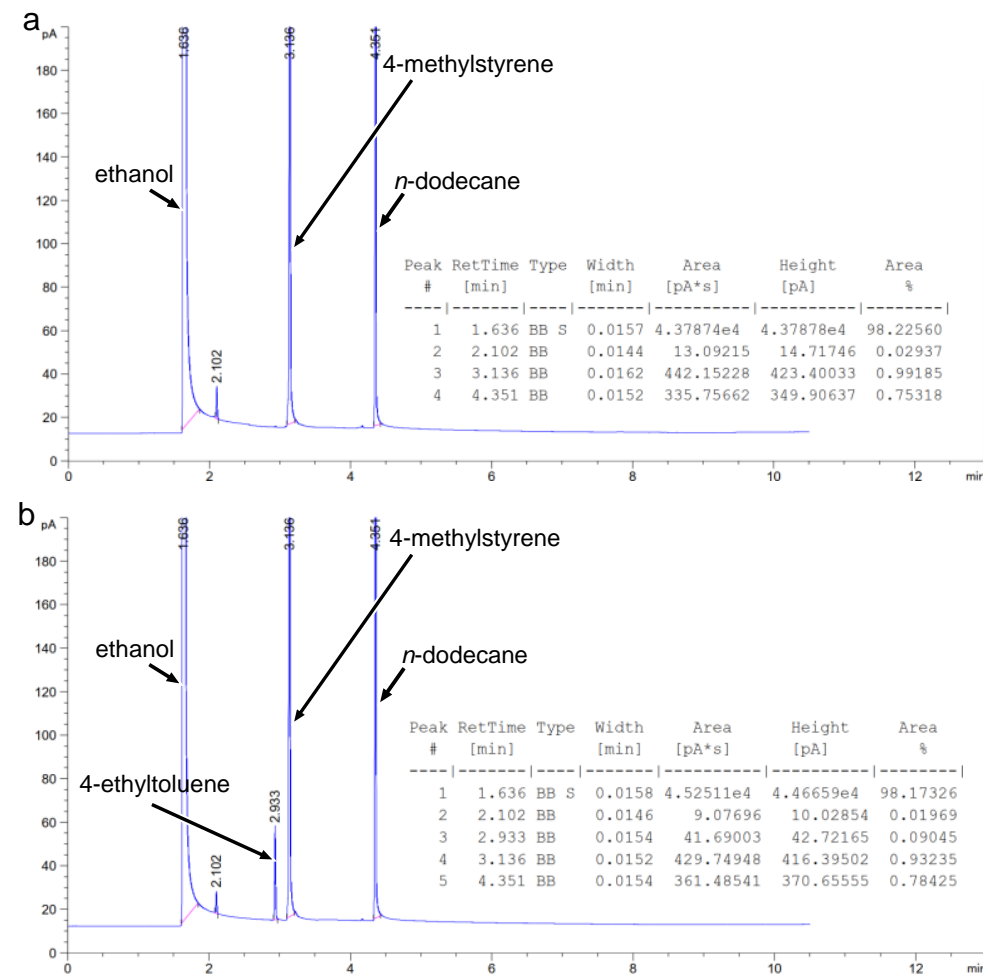

Figure S7. GC chromatograms of 4-methylstyrene hydrogenation using $\mathrm{Pd} / \mathrm{FeO}_{\mathrm{x}} @ \mathrm{SiO}_{2}-600$ as catalyst: (a) before reaction (at time $=0$ ), and (b) after reaction $(120 \mathrm{~min}$ ). Reaction conditions: 1 mmol of 4-methylstyrene, $10 \mathrm{~mL}$ of ethanol, $0.1 \mathrm{~mL}$ of $n$-dodecane (as internal standard), $\mathrm{H}_{2}$ flow $\left(30 \mathrm{~mL} \cdot \mathrm{min}^{-1}\right), 120 \mathrm{~min}$ at room temperature and atmospheric pressure. $\mathrm{GC}$ operating conditions: inlet temperature at $250{ }^{\circ} \mathrm{C}$, FID temperature at $280^{\circ} \mathrm{C}$, and oven at $70-280{ }^{\circ} \mathrm{C}$ with the ramp rate of $20{ }^{\circ} \mathrm{C} / \mathrm{min}$. 

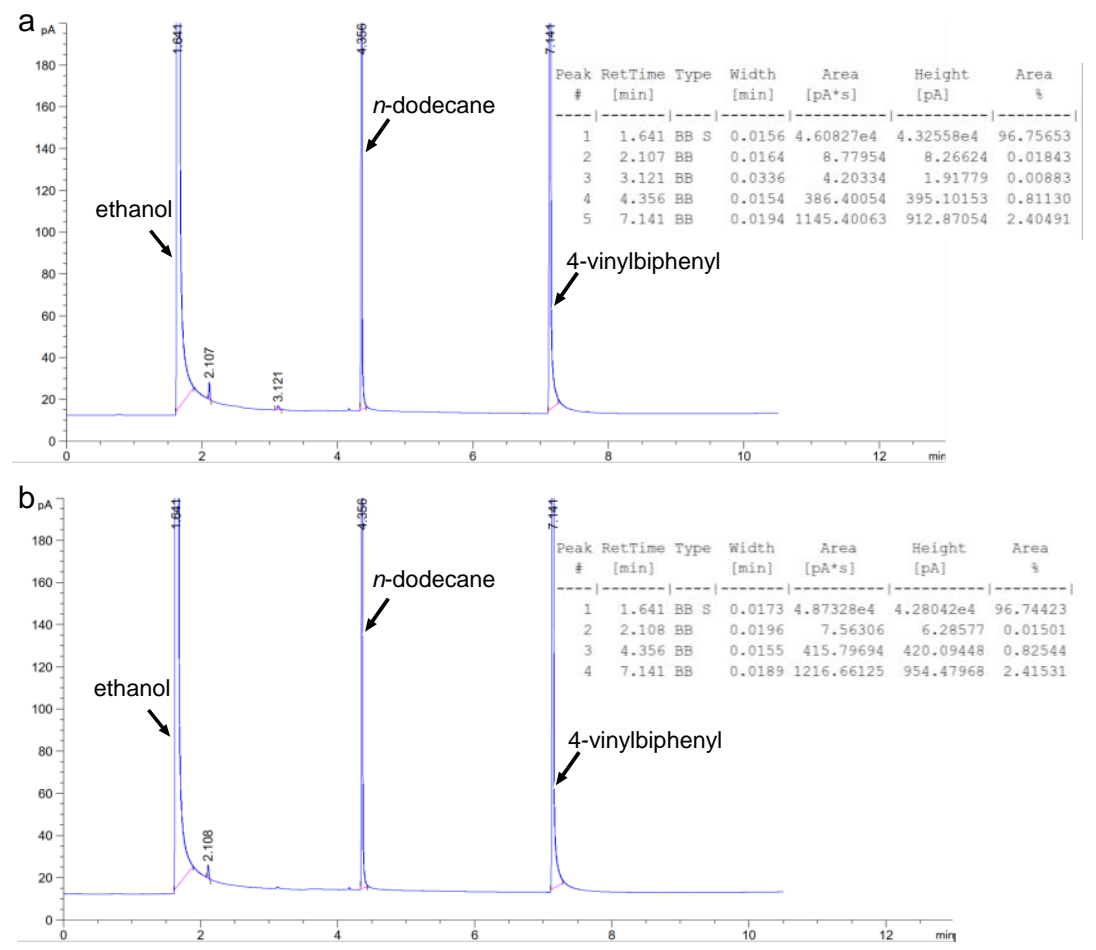

Figure S8. GC chromatograms of 4-vinylbiphenyl hydrogenation using $\mathrm{Pd} / \mathrm{FeO}_{\mathrm{x}} @ \mathrm{SiO}_{2}-600$ as catalyst: (a) before reaction (at time $=0$ ), and (b) after reaction (120 min). Reaction conditions: 1 mmol of 4-vinylbiphenyl, $10 \mathrm{~mL}$ of ethanol, $0.1 \mathrm{~mL}$ of $n$-dodecane (as internal standard), $\mathrm{H}_{2}$ flow $\left(30 \mathrm{~mL} \cdot \mathrm{min}^{-1}\right), 120 \mathrm{~min}$ at room temperature and atmospheric pressure. $\mathrm{GC}$ operating conditions: inlet temperature at $250{ }^{\circ} \mathrm{C}$, FID temperature at $280^{\circ} \mathrm{C}$, and oven at $70-280{ }^{\circ} \mathrm{C}$ with the ramp rate of $20{ }^{\circ} \mathrm{C} / \mathrm{min}$.
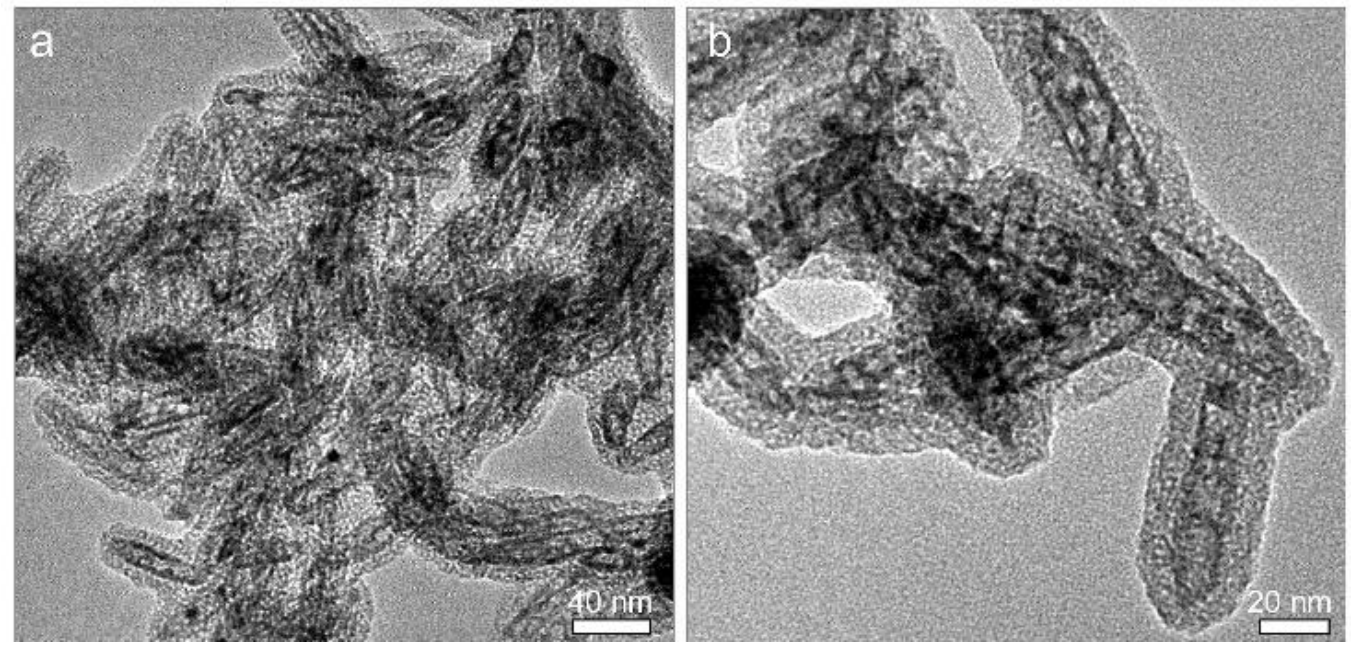

Figure S9. TEM images at different magnifications $(\mathrm{a}, \mathrm{b})$ of $\mathrm{Pd} / \mathrm{FeO}_{\mathrm{x}} @ m \mathrm{SiO}_{2}$ sample in which the silica shell is mesoporous $\left(m \mathrm{SiO}_{2}\right)$. 
a

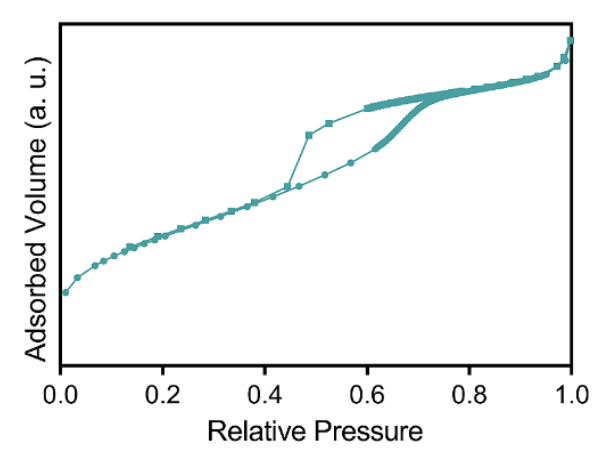

b

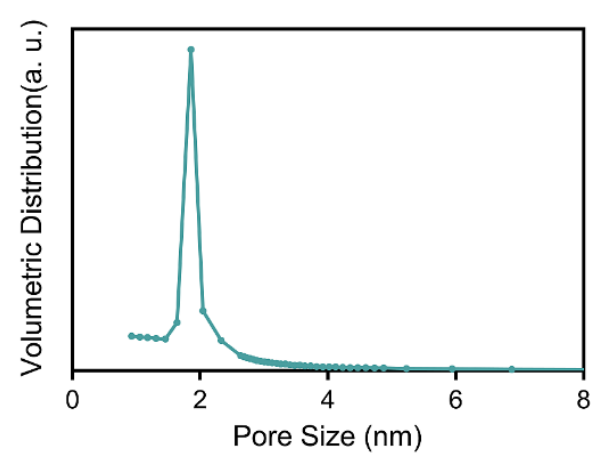

Figure S10. (a) Isothermal nitrogen adsorption-desorption loop and (b) corresponding pore size distribution of $\mathrm{Pd} / \mathrm{FeO}_{\mathrm{x}} @ m \mathrm{SiO}_{2}$ sample in which the silica shell is mesoporous $\left(m \mathrm{SiO}_{2}\right)$.
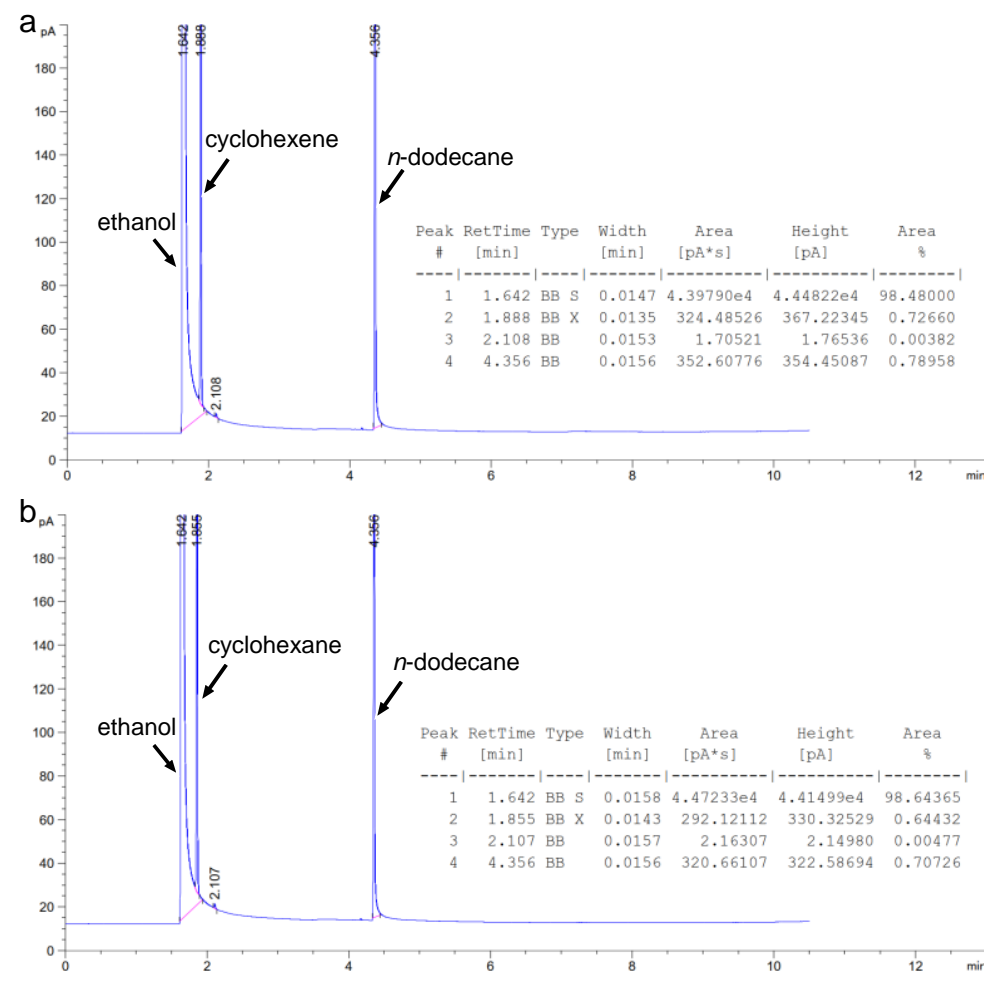

Figure S11. GC chromatograms of cyclohexene hydrogenation using $\mathrm{Pd} / \mathrm{FeO}_{\mathrm{x}} @ m \mathrm{SiO}_{2}$ as catalyst: (a) before reaction (at time $=0$ ), and (b) after reaction (60 min). Reaction conditions: $1 \mathrm{mmol}$ of cyclohexene, $10 \mathrm{~mL}$ of ethanol, $0.1 \mathrm{~mL}$ of $n$-dodecane (as internal standard), $\mathrm{H}_{2}$ flow $\left(30 \mathrm{~mL} \cdot \mathrm{min}^{-1}\right.$ ), $60 \mathrm{~min}$ at room temperature and atmospheric pressure. GC operating conditions: inlet temperature at $250{ }^{\circ} \mathrm{C}$, FID temperature at $280^{\circ} \mathrm{C}$, and oven at $70-280{ }^{\circ} \mathrm{C}$ with the ramp rate of $20^{\circ} \mathrm{C} / \mathrm{min}$. 

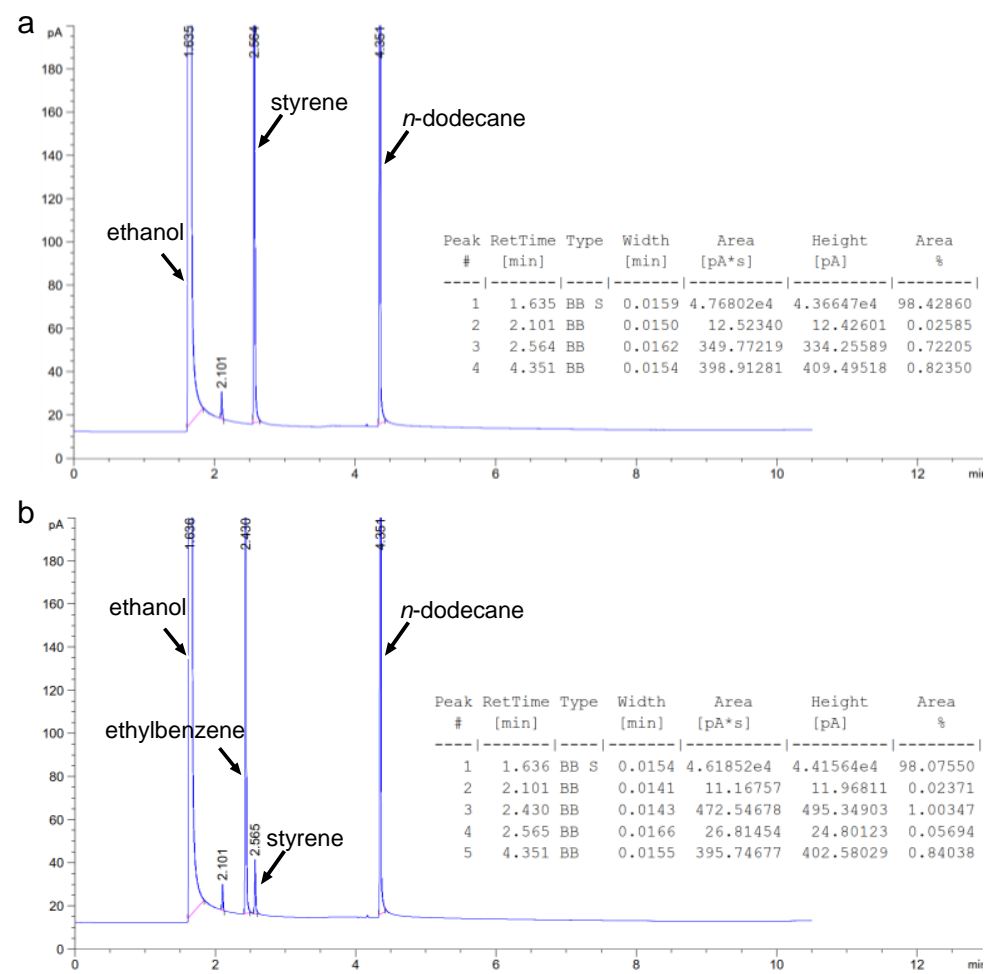

Figure S12. GC chromatograms of styrene hydrogenation using $\mathrm{Pd} / \mathrm{FeO}_{x} @ m \mathrm{SiO}_{2}$ as catalyst: (a) before reaction (at time $=0$ ), and (b) after reaction $(60 \mathrm{~min}$ ). Reaction conditions: $1 \mathrm{mmol}$ of styrene, $10 \mathrm{~mL}$ of ethanol, $0.1 \mathrm{~mL}$ of $n$-dodecane (as internal standard), $\mathrm{H}_{2}$ flow $\left(30 \mathrm{~mL} \cdot \mathrm{min}^{-1}\right), 60 \mathrm{~min}$ at room temperature and atmospheric pressure. $\mathrm{GC}$ operating conditions: inlet temperature at $250{ }^{\circ} \mathrm{C}$, FID temperature at $280{ }^{\circ} \mathrm{C}$, and oven at $70-280{ }^{\circ} \mathrm{C}$ with the ramp rate of $20^{\circ} \mathrm{C} / \mathrm{min}$. 

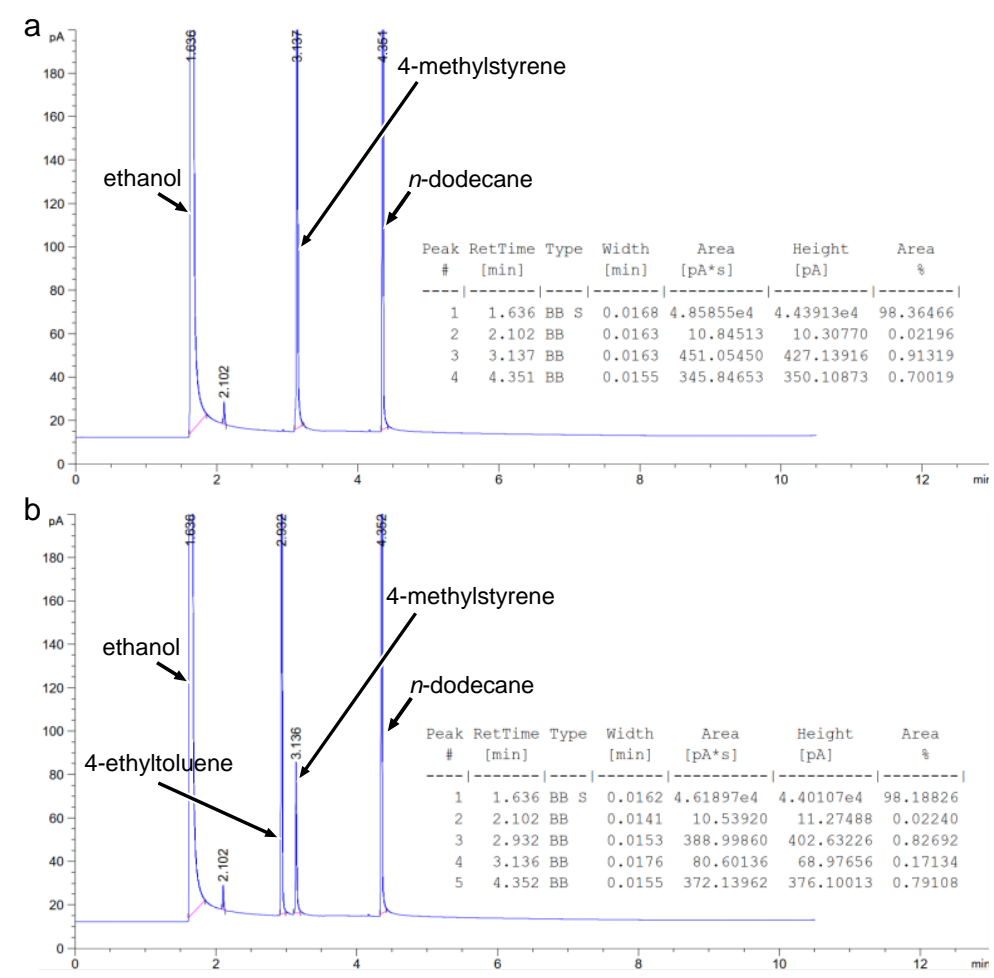

Figure S13. GC chromatograms of 4-methylstyrene hydrogenation using $\mathrm{Pd} / \mathrm{FeO}_{\mathrm{x}} @ m \mathrm{SiO}_{2}$ as catalyst: (a) before reaction (at time $=0$ ), and (b) after reaction (60 min). Reaction conditions: 1 mmol of 4-methylstyrene, $10 \mathrm{~mL}$ of ethanol, $0.1 \mathrm{~mL}$ of $n$-dodecane (as internal standard), $\mathrm{H}_{2}$ flow $\left(30 \mathrm{~mL} \cdot \mathrm{min}^{-1}\right), 60 \mathrm{~min}$ at room temperature and atmospheric pressure. $\mathrm{GC}$ operating conditions: inlet temperature at $250{ }^{\circ} \mathrm{C}$, FID temperature at $280{ }^{\circ} \mathrm{C}$, and oven at $70-280{ }^{\circ} \mathrm{C}$ with the ramp rate of $20{ }^{\circ} \mathrm{C} / \mathrm{min}$. 


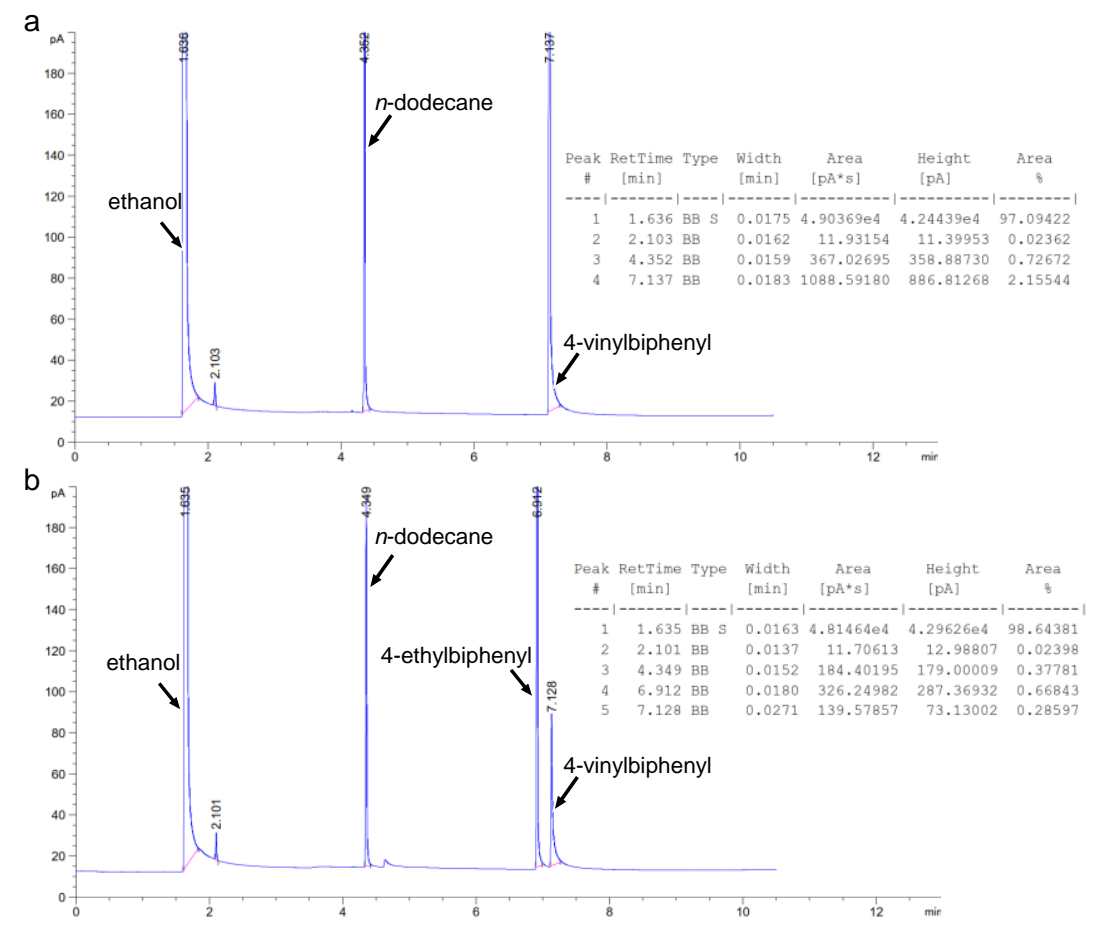

Figure S14. GC chromatograms of 4-vinylbiphenyl hydrogenation using $\mathrm{Pd} / \mathrm{FeO}_{\mathrm{x}} @ m \mathrm{SiO}_{2}$ as catalyst: (a) before reaction (at time $=0$ ), and (b) after reaction (60 min). Reaction conditions: 1 mmol of 4-vinylbiphenyl, $10 \mathrm{~mL}$ of ethanol, $0.1 \mathrm{~mL}$ of $n$-dodecane (as internal standard), $\mathrm{H}_{2}$ flow $\left(30 \mathrm{~mL} \cdot \mathrm{min}^{-1}\right), 60 \mathrm{~min}$ at room temperature and atmospheric pressure. $\mathrm{GC}$ operating conditions: inlet temperature at $250{ }^{\circ} \mathrm{C}$, FID temperature at $280{ }^{\circ} \mathrm{C}$, and oven at $70-280{ }^{\circ} \mathrm{C}$ with the ramp rate of $20{ }^{\circ} \mathrm{C} / \mathrm{min}$. 


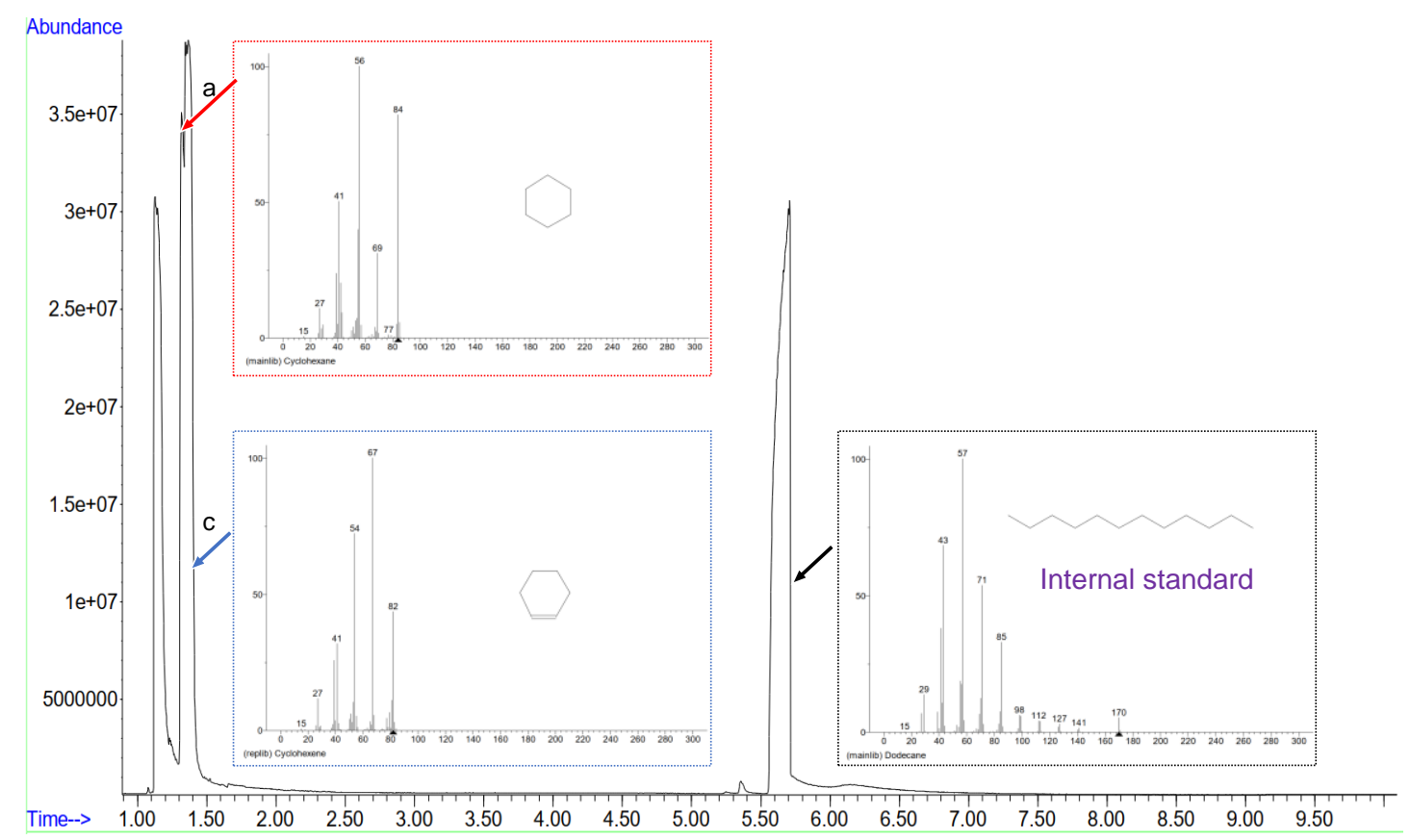

Figure S15. GC-MS chromatogram of cyclohexene hydrogenation using $\mathrm{Pd} / \mathrm{FeO}_{x} @ m \mathrm{SiO}_{2}$ as catalyst after reaction for $30 \mathrm{~min}$. Reaction conditions: $1 \mathrm{mmol}$ of cyclohexene, $10 \mathrm{~mL}$ of ethanol, $0.1 \mathrm{~mL}$ of $n$-dodecane (as internal standard), $\mathrm{H}_{2}$ flow $\left(30 \mathrm{~mL} \cdot \mathrm{min}^{-1}\right), 30 \mathrm{~min}$ at room temperature and atmospheric pressure. GC operating conditions: inlet temperature at $250^{\circ} \mathrm{C}$, FID temperature at $280^{\circ} \mathrm{C}$, and oven at $70-240{ }^{\circ} \mathrm{C}$ with the ramp rate of $20^{\circ} \mathrm{C} / \mathrm{min}$.

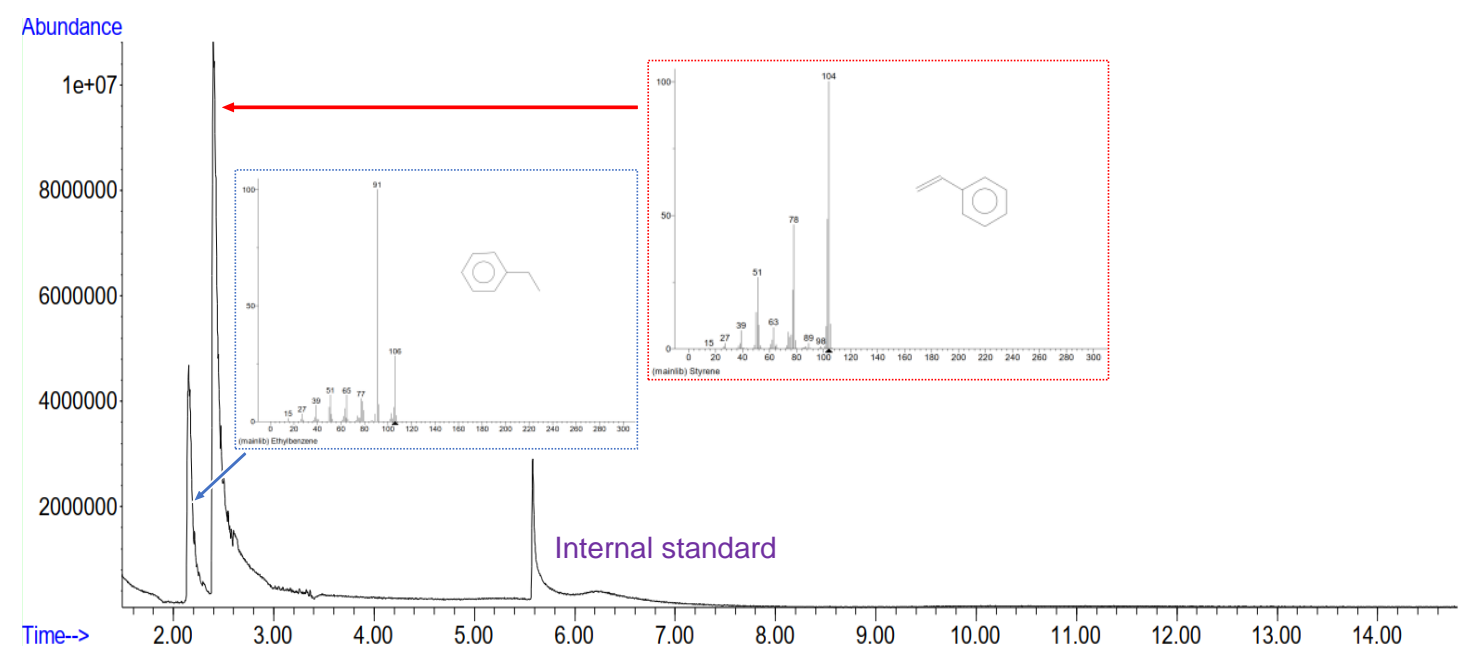

Figure S16. GC-MS chromatogram of styrene hydrogenation using $\mathrm{Pd} / \mathrm{FeO}_{x} @ m \mathrm{SiO}_{2}$ as catalyst after reaction for $30 \mathrm{~min}$. Reaction conditions: $1 \mathrm{mmol}$ of styrene, $10 \mathrm{~mL}$ of ethanol, $0.1 \mathrm{~mL}$ of $n$-dodecane (as internal standard), $\mathrm{H}_{2}$ flow $\left(30 \mathrm{~mL} \cdot \mathrm{min}^{-1}\right), 30 \mathrm{~min}$ at room temperature and atmospheric pressure. GC operating conditions: inlet temperature at $250{ }^{\circ} \mathrm{C}$, FID temperature at $280{ }^{\circ} \mathrm{C}$, and oven at 70 $280{ }^{\circ} \mathrm{C}$ with the ramp rate of $25^{\circ} \mathrm{C} / \mathrm{min}$ and hold at $280{ }^{\circ} \mathrm{C}$ for $5 \mathrm{~min}$. 


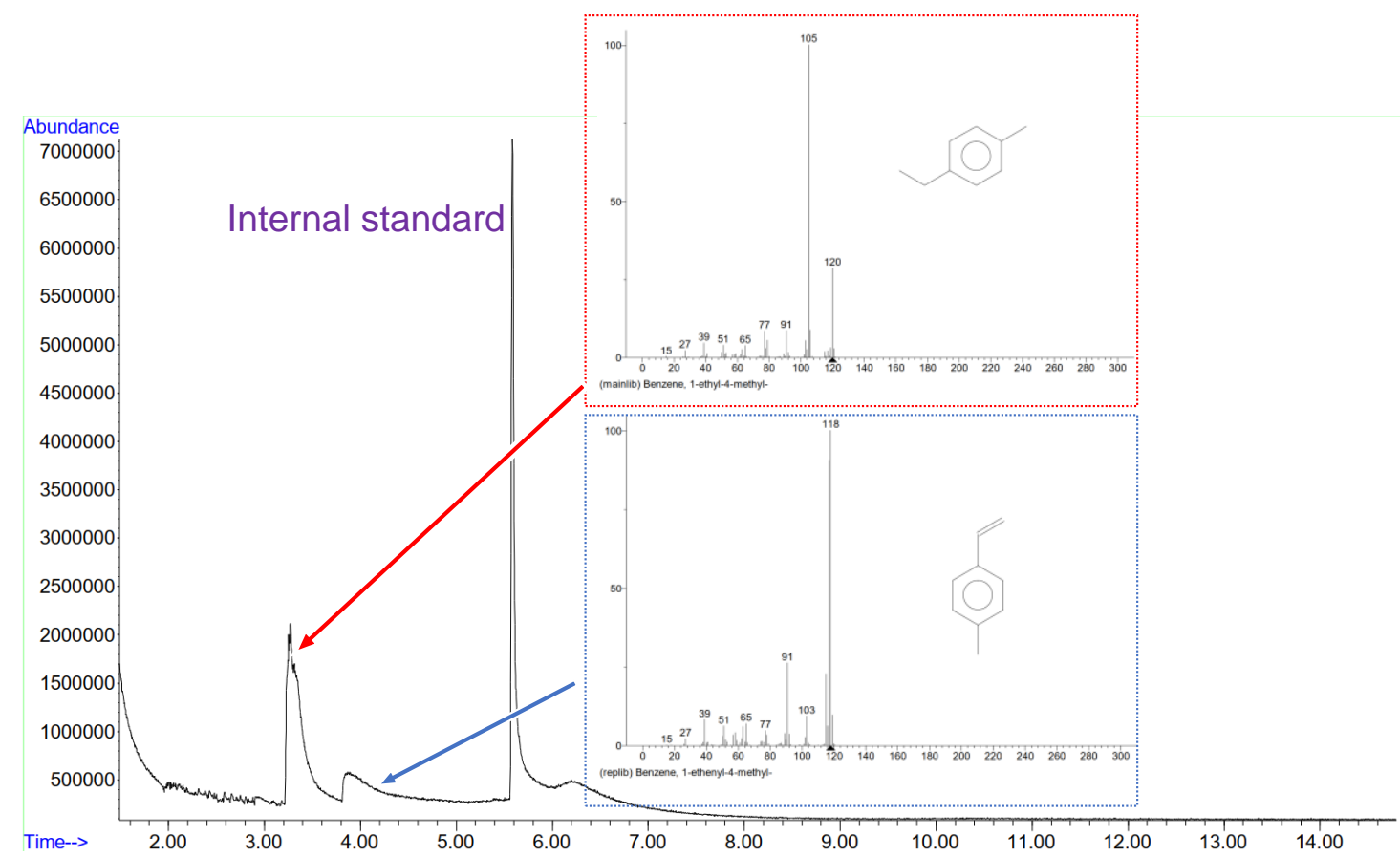

Figure S17. GC-MS chromatogram of 4-methylstyrene hydrogenation using $\mathrm{Pd} / \mathrm{FeO}_{\mathrm{x}} @ m \mathrm{SiO}_{2}$ as catalyst after reaction for $60 \mathrm{~min}$. Reaction conditions: $1 \mathrm{mmol}$ of 4-methylstyrene, $10 \mathrm{~mL}$ of ethanol, $0.1 \mathrm{~mL}$ of $n$-dodecane (as internal standard), $\mathrm{H}_{2}$ flow $\left(30 \mathrm{~mL} \cdot \mathrm{min}^{-1}\right), 60 \mathrm{~min}$ at room temperature and atmospheric pressure. GC operating conditions: inlet temperature at $250^{\circ} \mathrm{C}$, FID temperature at $280{ }^{\circ} \mathrm{C}$, and oven at $70-280{ }^{\circ} \mathrm{C}$ with the ramp rate of $25^{\circ} \mathrm{C} / \mathrm{min}$ and hold at $280{ }^{\circ} \mathrm{C}$ for $5 \mathrm{~min}$.

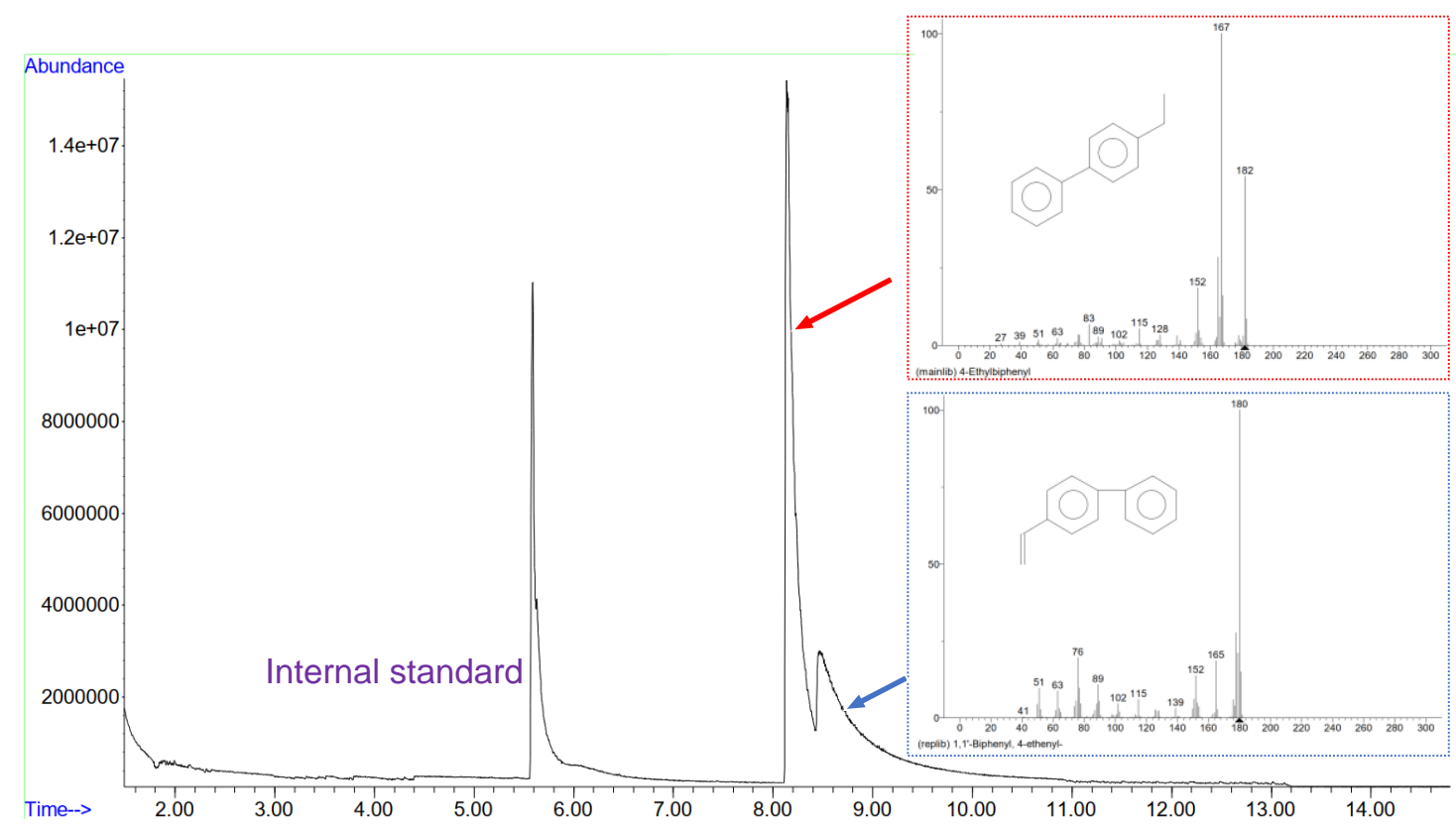

Figure S18. GC-MS chromatogram of 4-vinylbiphenyl hydrogenation using $\mathrm{Pd} / \mathrm{FeO}_{\mathrm{x}} @ m \mathrm{SiO}_{2}$ as catalyst after reaction for $60 \mathrm{~min}$. Reaction conditions: $1 \mathrm{mmol}$ of 4-vinylbiphenyl, $10 \mathrm{~mL}$ of ethanol, $0.1 \mathrm{~mL}$ of $n$-dodecane (as internal standard), $\mathrm{H}_{2}$ flow $\left(30 \mathrm{~mL} \cdot \mathrm{min}^{-1}\right), 60 \mathrm{~min}$ at room temperature and atmospheric pressure. GC operating conditions: inlet temperature at $250{ }^{\circ} \mathrm{C}$, FID temperature at $280{ }^{\circ} \mathrm{C}$, and oven at $70-280{ }^{\circ} \mathrm{C}$ with the ramp rate of $25^{\circ} \mathrm{C} / \mathrm{min}$ and hold at $280{ }^{\circ} \mathrm{C}$ for $5 \mathrm{~min}$. 

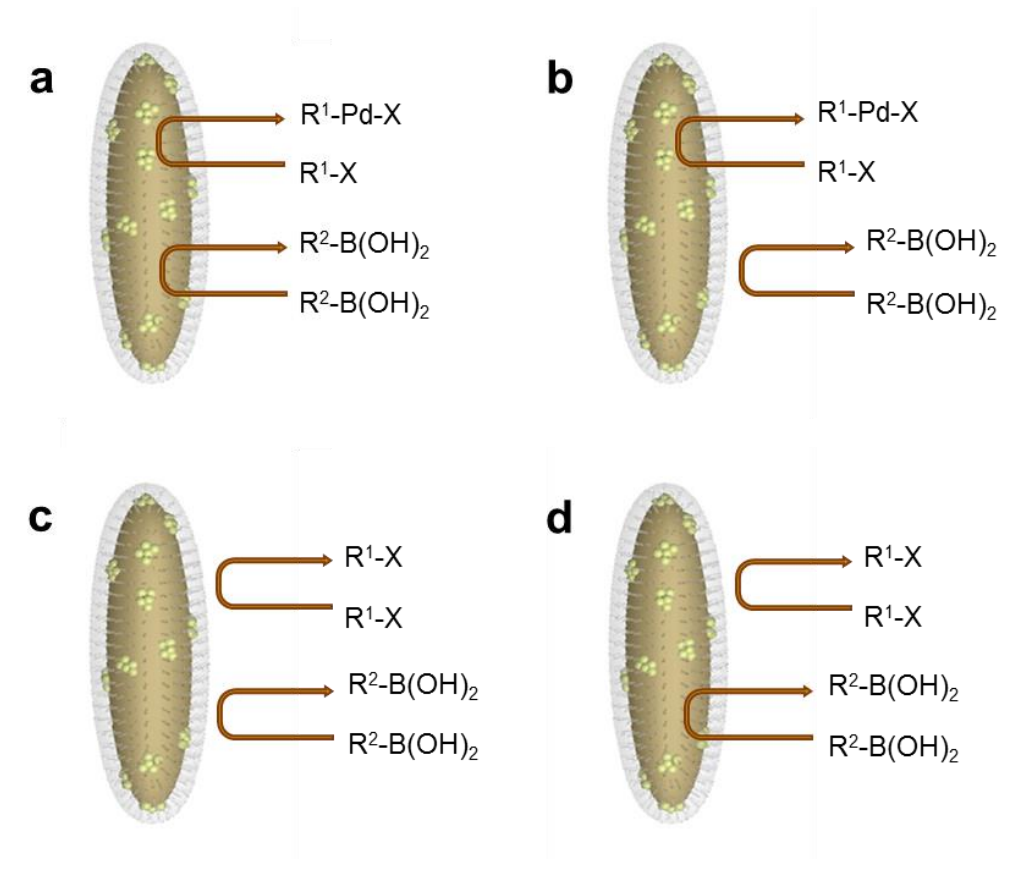

Figure S19. Size selective cross-coupling reactions: (a) both $\mathrm{R}^{1}-\mathrm{X}$ and $\mathrm{R}^{2}-\mathrm{B}(\mathrm{OH})_{2}$ are small, (b) $\mathrm{R}^{1}$ $\mathrm{X}$ is small but $\mathrm{R}^{2}-\mathrm{B}(\mathrm{OH})_{2}$ is large, (c) both $\mathrm{R}^{1}-\mathrm{X}$ and $\mathrm{R}^{2}-\mathrm{B}(\mathrm{OH})_{2}$ are large, and (d) $\mathrm{R}^{1}-\mathrm{X}$ is large but $\mathrm{R}^{2}-\mathrm{B}(\mathrm{OH})_{2}$ is small, where $\mathrm{R}^{1}$ and $\mathrm{R}^{2}$ are aryl functional groups of aryl halides and arylboronic acids, respectively (Table S3). Pd atoms or cations are represented by small light olive spheres; $\mathrm{FeO}_{\mathrm{x}}$ support of solid Pd is illustrated as spindle-like core with cider color; and microporous silica shell in gray is depicted as the outmost layer on the $\mathrm{Pd} / \mathrm{FeO}_{\mathrm{x}}$ core; the soluble base used in the reaction is not indicated above. 


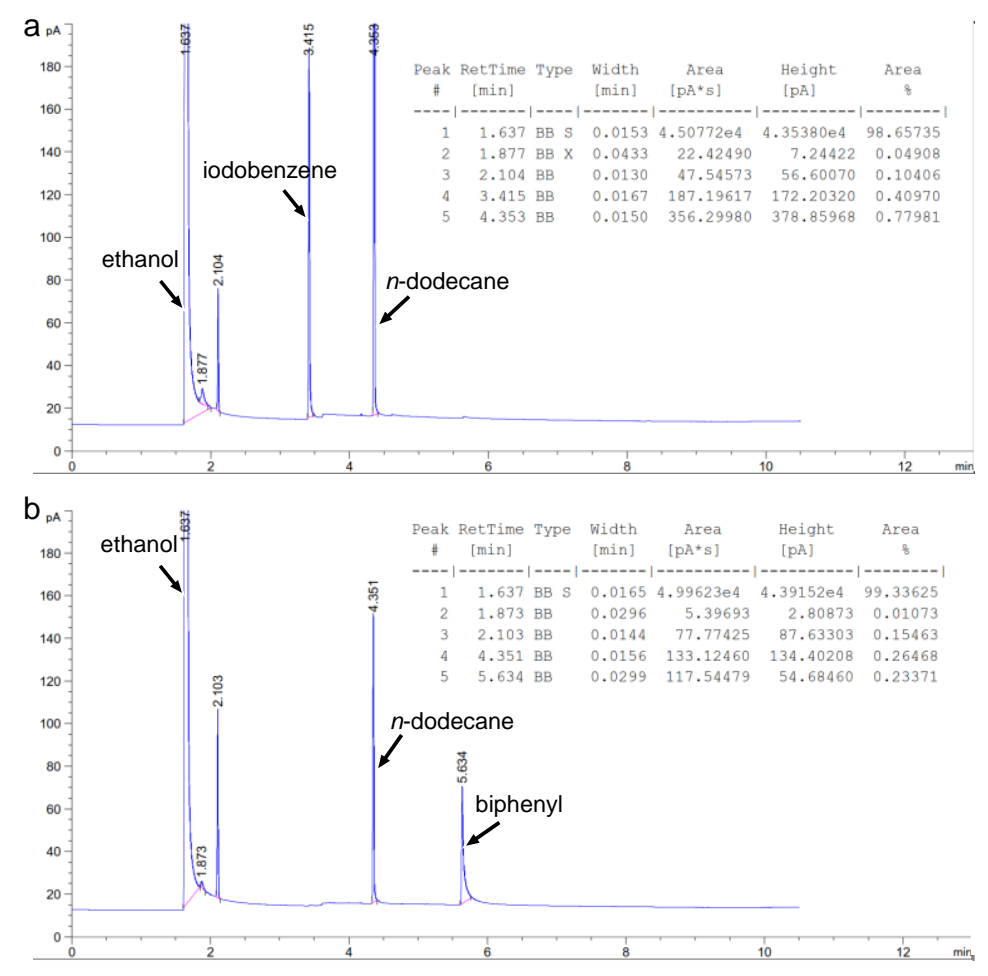

Figure S20. GC chromatograms of Suzuki coupling reaction between iodobenzene and phenylboronic acid using $\mathrm{Pd} / \mathrm{FeO}_{\mathrm{x}} @ \mathrm{SiO}_{2}-600$ as catalyst: (a) before reaction (at time = 0), and (b) after reaction (120 min). Reaction conditions: $0.5 \mathrm{mmol}$ of iodobenzene, $1 \mathrm{mmol}$ of phenylboronic acid, $0.1 \mathrm{~mL}$ of $n$-dodecane (as an internal standard for GC), $2 \mathrm{mmol}$ of $\mathrm{K}_{2} \mathrm{CO}_{3}, 120 \mathrm{~min}$ at $85^{\circ} \mathrm{C}$. GC operating conditions: inlet temperature at $250^{\circ} \mathrm{C}$, FID temperature at $280^{\circ} \mathrm{C}$, and oven at $70-$ $280{ }^{\circ} \mathrm{C}$ with the ramp rate of $20^{\circ} \mathrm{C} / \mathrm{min}$. The product was also analyzed by NMR (Figure S23). 

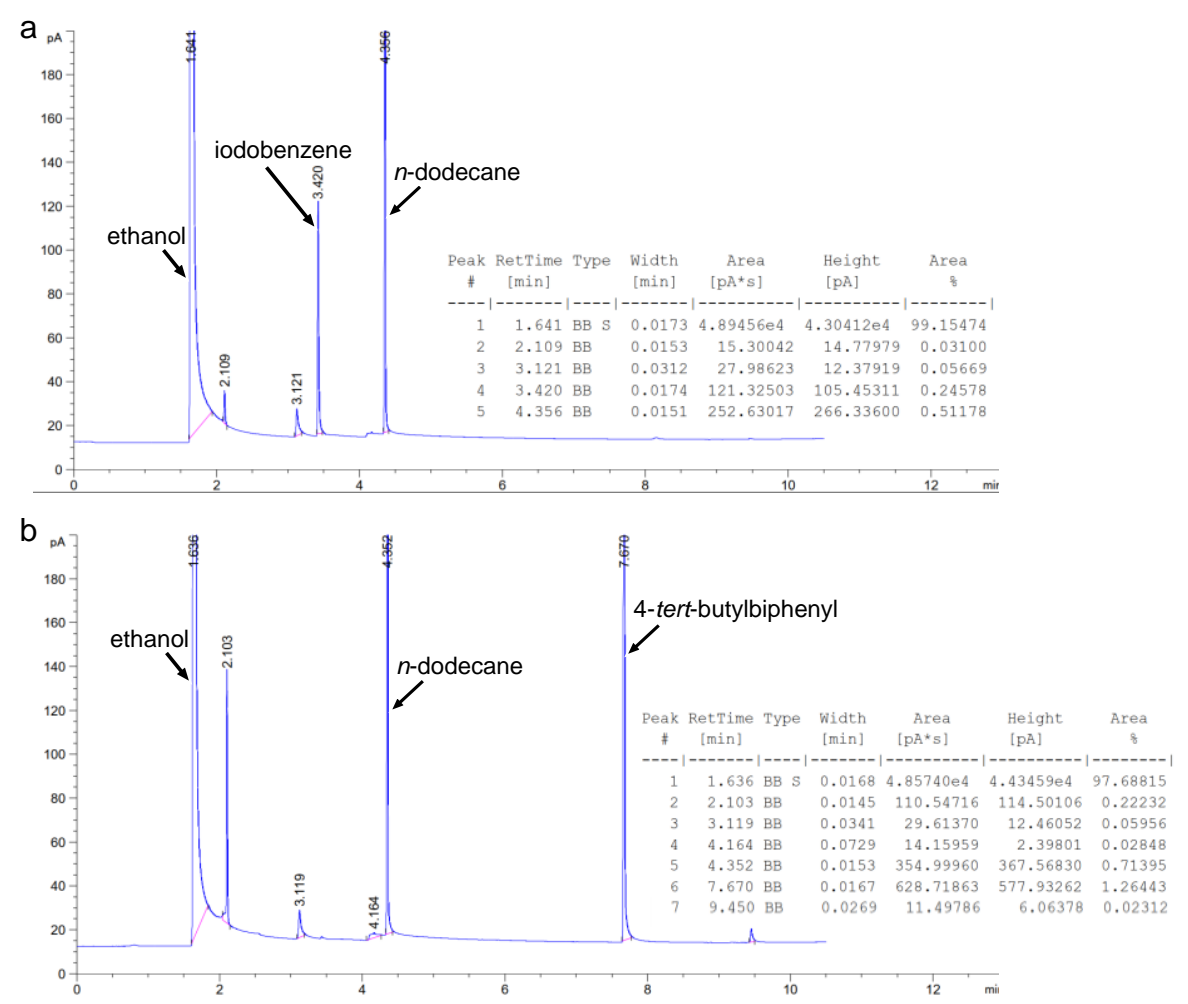

Figure S21. GC chromatograms of Suzuki coupling reaction between iodobenzene and 4-tertbutylphenylboronic acid using $\mathrm{Pd} / \mathrm{FeO}_{\mathrm{x}} @ \mathrm{SiO}_{2}-600$ as catalyst: (a) before reaction (at time $=0$ ), and (b) after reaction $(120 \mathrm{~min})$. Reaction conditions: $0.5 \mathrm{mmol}$ of iodobenzene, $1 \mathrm{mmol}$ of 4-tertbutylphenylboronic acid, $0.1 \mathrm{~mL}$ of $n$-dodecane (as an internal standard for GC), $2 \mathrm{mmol}$ of $\mathrm{K}_{2} \mathrm{CO}_{3}$, $120 \mathrm{~min}$ at $85^{\circ} \mathrm{C}$. GC operating conditions: inlet temperature at $250{ }^{\circ} \mathrm{C}$, FID temperature at $280^{\circ} \mathrm{C}$, and oven at $70-280{ }^{\circ} \mathrm{C}$ with the ramp rate of $20^{\circ} \mathrm{C} / \mathrm{min}$. The product was also analyzed by NMR (Figure S24). 


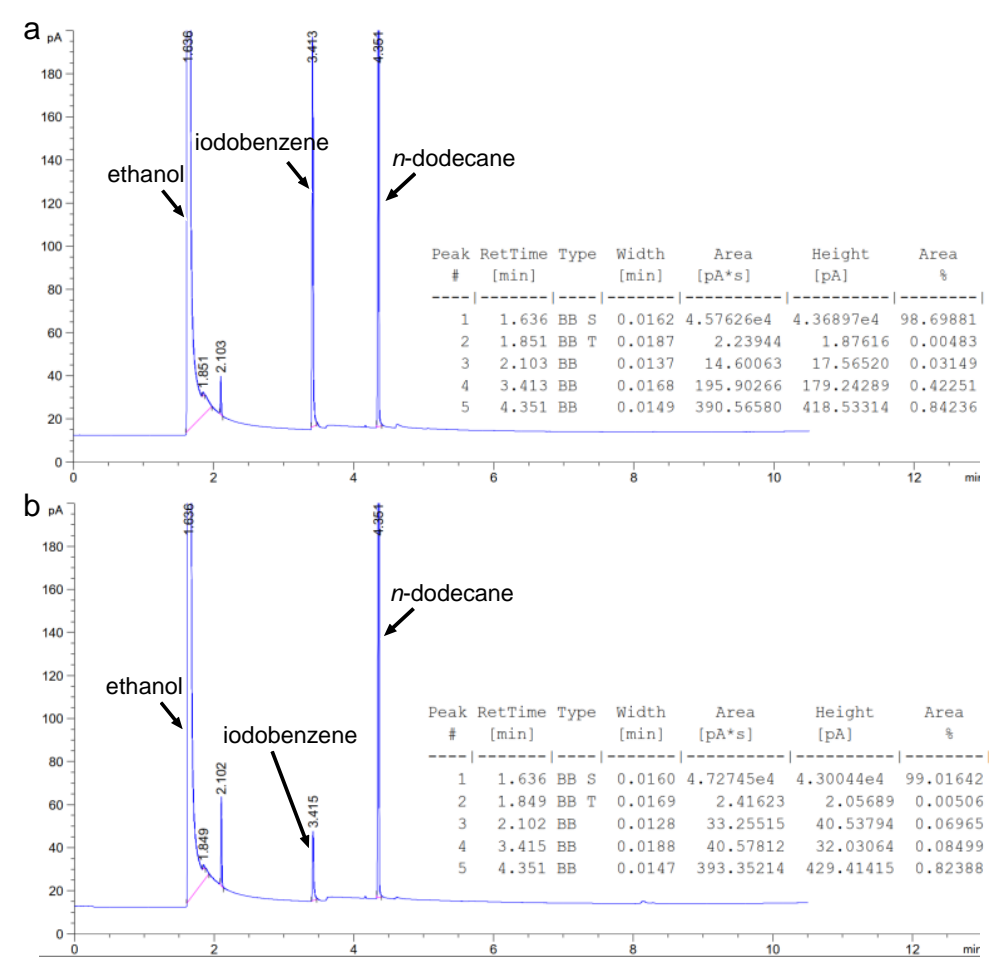

Figure S22. GC chromatograms of Suzuki coupling reaction between iodobenzene and 4benzyloxyphenylboronic acid using $\mathrm{Pd} / \mathrm{FeO}_{\mathrm{x}} @ \mathrm{SiO}_{2}-600$ as catalyst: (a) before reaction (at time $=0$ ), and (b) after reaction (120 $\mathrm{min})$. Reaction conditions: $0.5 \mathrm{mmol}$ of iodobenzene, $1 \mathrm{mmol}$ of 4benzyloxyphenylboronic acid, $0.1 \mathrm{~mL}$ of $n$-dodecane (as an internal standard for GC), $2 \mathrm{mmol}$ of $\mathrm{K}_{2} \mathrm{CO}_{3}, 120 \mathrm{~min}$ at $85^{\circ} \mathrm{C}$. GC operating conditions: inlet temperature at $250{ }^{\circ} \mathrm{C}$, FID temperature at $280^{\circ} \mathrm{C}$, and oven at $70-280{ }^{\circ} \mathrm{C}$ with the ramp rate of $20^{\circ} \mathrm{C} / \mathrm{min}$. Due to its low solubility and high boiling point, the product for this reaction was not detected under our GC setting. The product was then analyzed by NMR (Figure S25). 
a

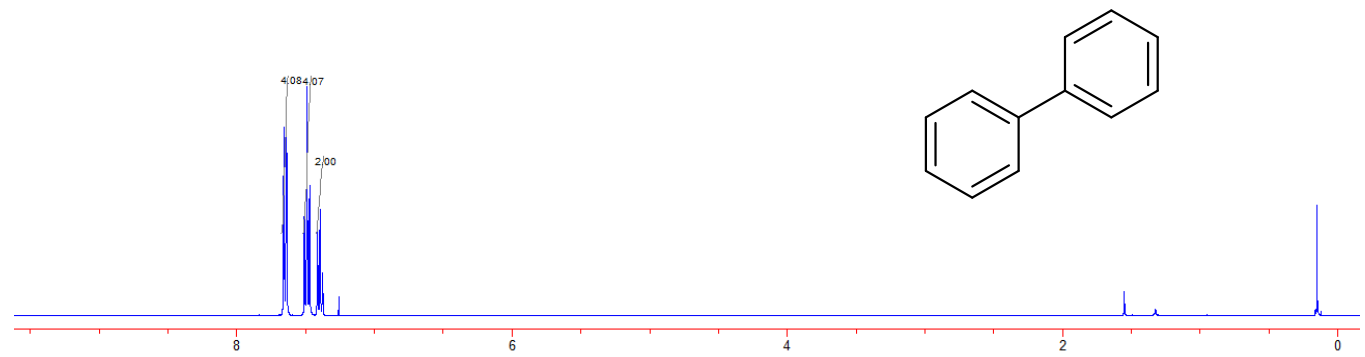

b
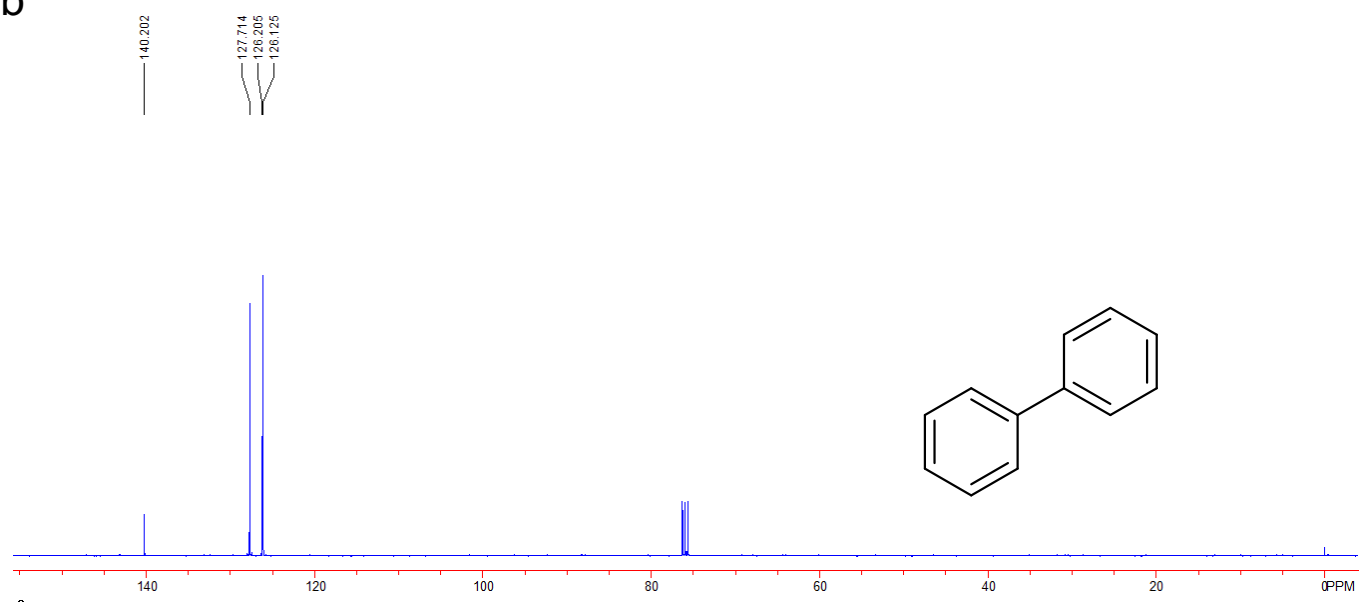

Figure S23. Spectroscopic data of the products for the reaction between iodobenzene and phenylboronic acid. a) ${ }^{1} \mathbf{H}$ NMR (400 MHz, $\left.\mathbf{C D C l}_{3}\right) \delta$ 7.66-7.63 (m, 4H), 7.51-7.47 (m, 4H), 7.41$7.37(\mathrm{dt}, \mathrm{J}=8 \mathrm{~Hz}, \mathrm{~J}=1 \mathrm{~Hz}, 2 \mathrm{H})$. b) ${ }^{13} \mathbf{C} \mathbf{~ N M R}\left(\mathbf{1 0 0} \mathbf{M H z}, \mathbf{C D C l}_{3}\right) \delta 140.2,127.7,126.2,126.1$.

Comments: ${ }^{1} \mathrm{H}$ NMR spectra were recorded on Bruker $400 \mathrm{MHz}$ spectrometer. Chemical shifts are reported in ppm from tetramethylsilane with the solvent resonance resulting from incomplete deuterium incorporation as the internal standard $\left(\mathrm{CDCl}_{3}: \delta 7.26 \mathrm{ppm}\right)$. Data are reported as follows: chemical shift, integration, multiplicity $(\mathrm{s}=$ singlet, $\mathrm{d}=$ doublet, $\mathrm{dt}=$ double triplet; $\mathrm{dd}=$ double doublet, $\mathrm{t}=$ triplet, $\mathrm{q}=$ quartet, $\mathrm{br}=$ broad, $\mathrm{m}=$ multiplet $)$, and coupling constants $(\mathrm{Hz}) .{ }^{13} \mathrm{C} \mathrm{NMR}$ spectra were recorded on Bruker $400 \mathrm{MHz}$ spectrometer with complete proton decoupling. Chemical shifts are reported in ppm from tetramethylsilane with the solvent resonance as the internal standard $\left(\mathrm{CDCl}_{3}: \delta 77.16 \mathrm{ppm}\right)$. All the NMR characterizations were conducted under the same conditions in this work. 
a
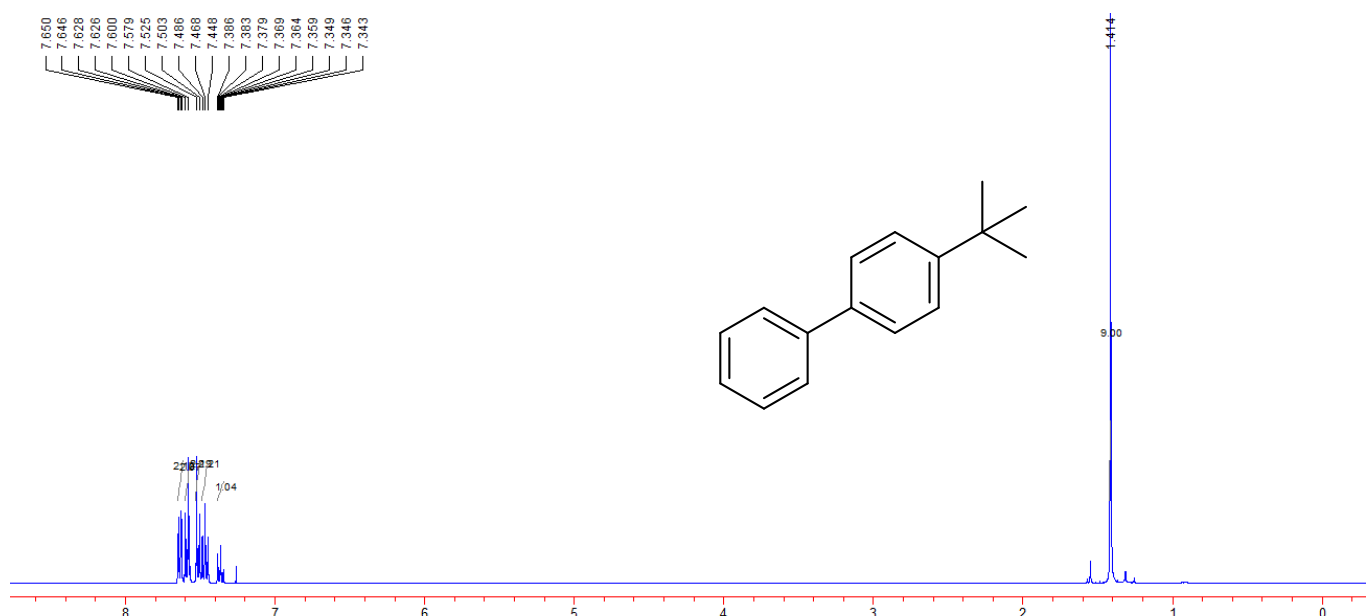

b

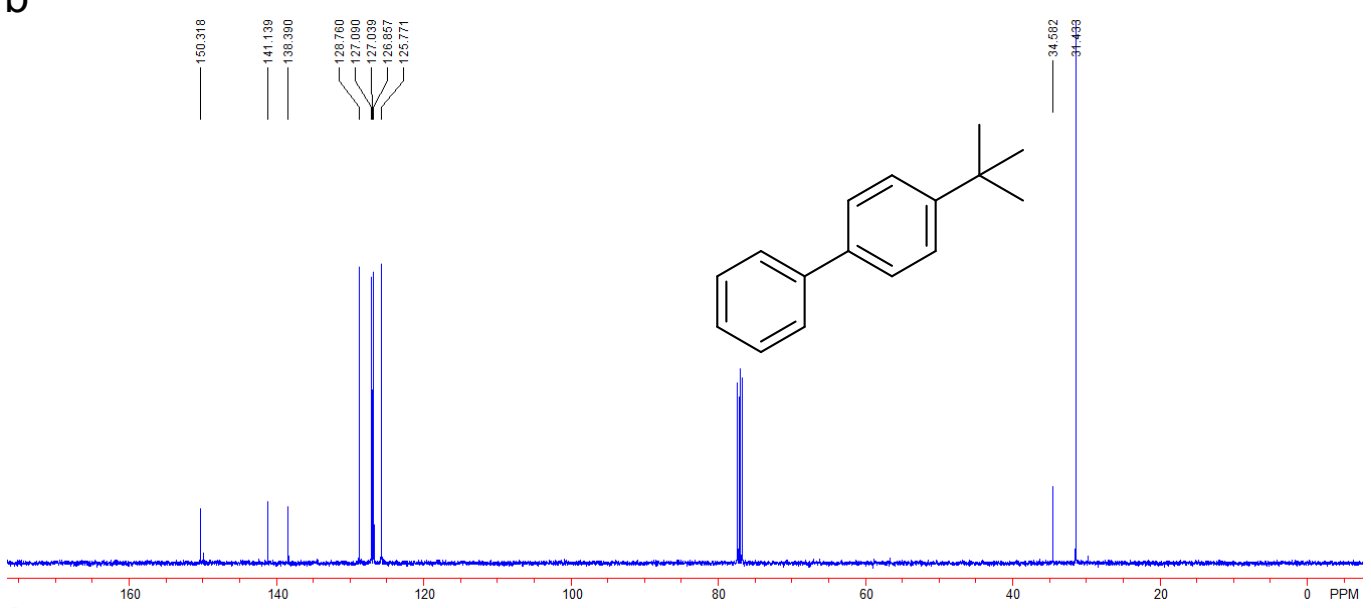

Figure S24. Spectroscopic data of the product for the reaction between iodobenzene and 4-tertbutylphenylboronic acid. (a) ${ }^{1} \mathbf{H}$ NMR (400 $\left.\mathbf{~ M H z}, \mathbf{C D C l}_{3}\right) \delta$ 7.65-7.62 (dd, J = $\left.8 \mathrm{~Hz}, \mathrm{~J}=1 \mathrm{~Hz}, 2 \mathrm{H}\right)$, 7.60-7.58 (d, J = $8 \mathrm{~Hz}, 2 \mathrm{H}), 7.52-7.50(\mathrm{~d}, \mathrm{~J}=8 \mathrm{~Hz}, 2 \mathrm{H}), 7.48-7.44(\mathrm{t}, \mathrm{J}=8 \mathrm{~Hz}, 2 \mathrm{H}), 7.38-7.34(\mathrm{dt}, \mathrm{J}$ $=8 \mathrm{~Hz}, \mathrm{~J}=1 \mathrm{~Hz}, 1 \mathrm{H}), 1.41$ (s, 9H). (b) ${ }^{\mathbf{1 3}} \mathbf{C}$ NMR (100 MHz, $\left.\mathbf{C D C l}_{\mathbf{3}}\right) \delta 150.3,141.1,138.3,128.7$, 127.1, 127.0, 126.8, 125.7, 34.5, 31.4. 
a
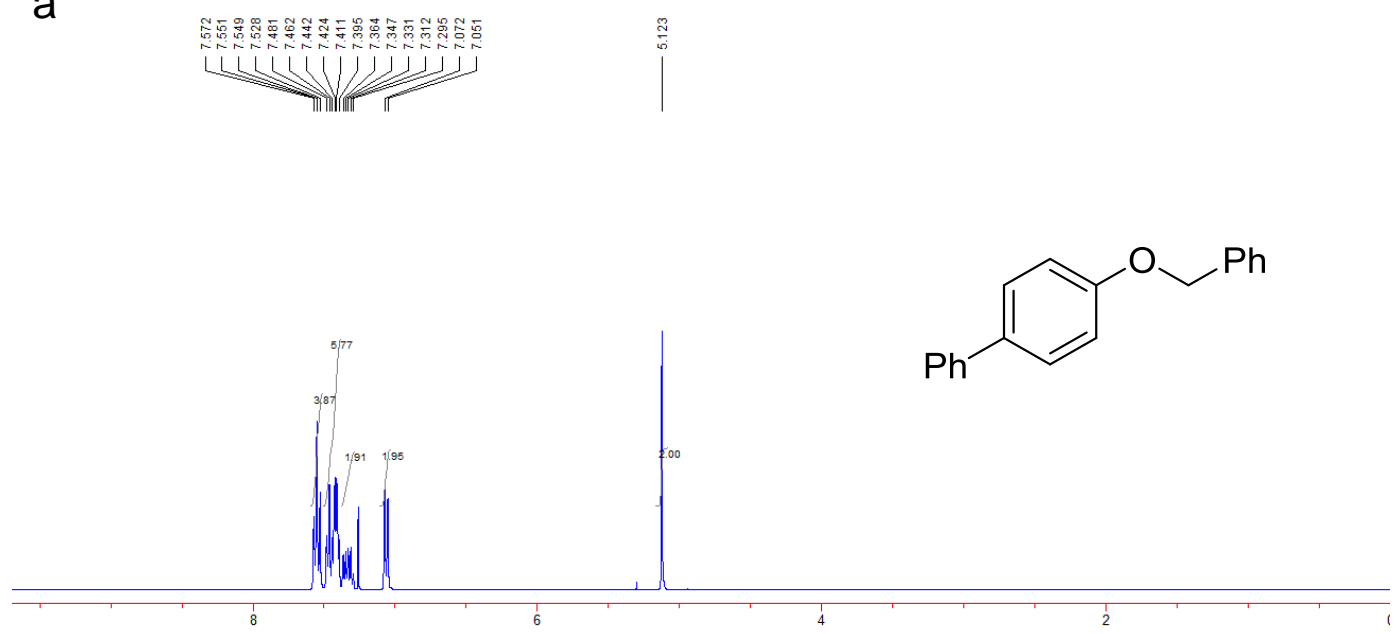

b

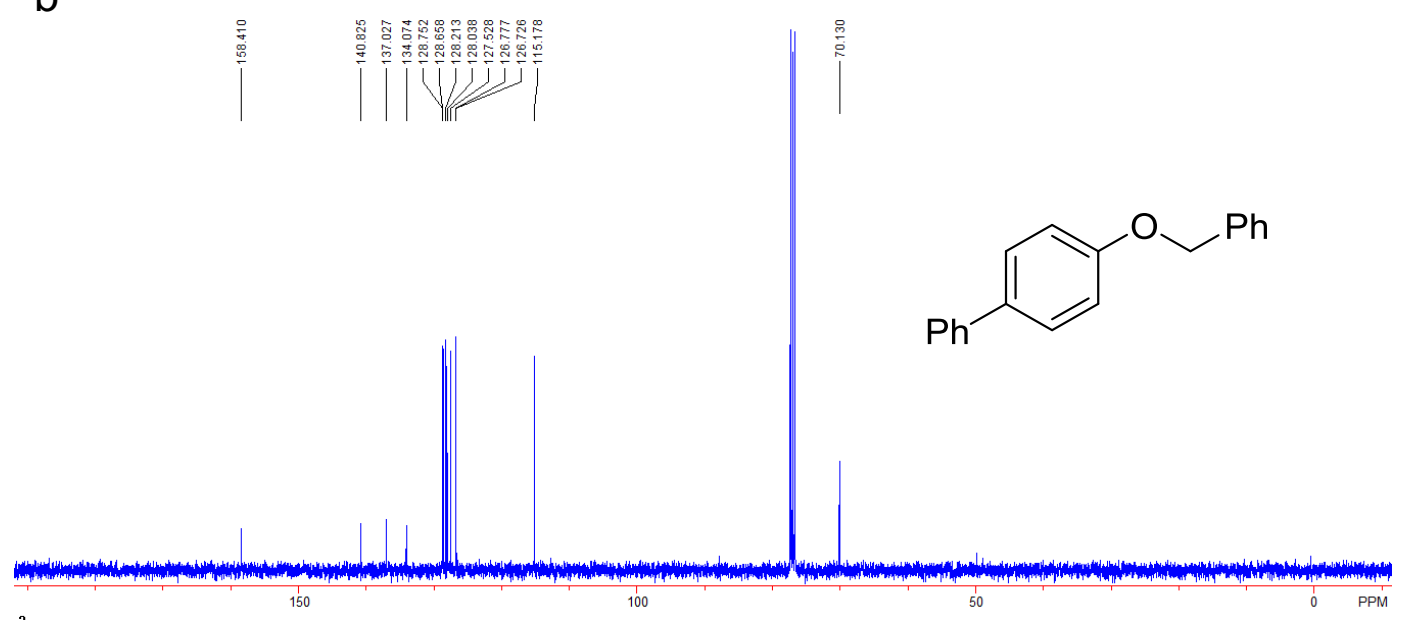

Figure S25. Spectroscopic data of the product for the reaction between iodobenzene and 4benzyloxyphenylboronic acid. (a) ${ }^{1} \mathbf{H}$ NMR (400 MHz, $\left.\mathbf{C D C l}_{3}\right) \delta 7.57-7.52(\mathrm{t}, J=8 \mathrm{~Hz}, 4 \mathrm{H}), 7.48$ $7.39(\mathrm{~m}, 6 \mathrm{H}), 7.36-7.29(\mathrm{~m}, 2 \mathrm{H}), 7.07-7.05(\mathrm{~d}, J=8 \mathrm{~Hz}, 2 \mathrm{H}), 5.12(\mathrm{~s}, 2 \mathrm{H}) .(\mathrm{b}){ }^{13} \mathbf{C}$ NMR (100 MHz, $\left.\mathbf{C D C l}_{3}\right) \delta 158.4,140.8,137.0,134.0,128.7,128.6,128.2,128.0,127.5,126.8,126.7,115.1,70.1$. 


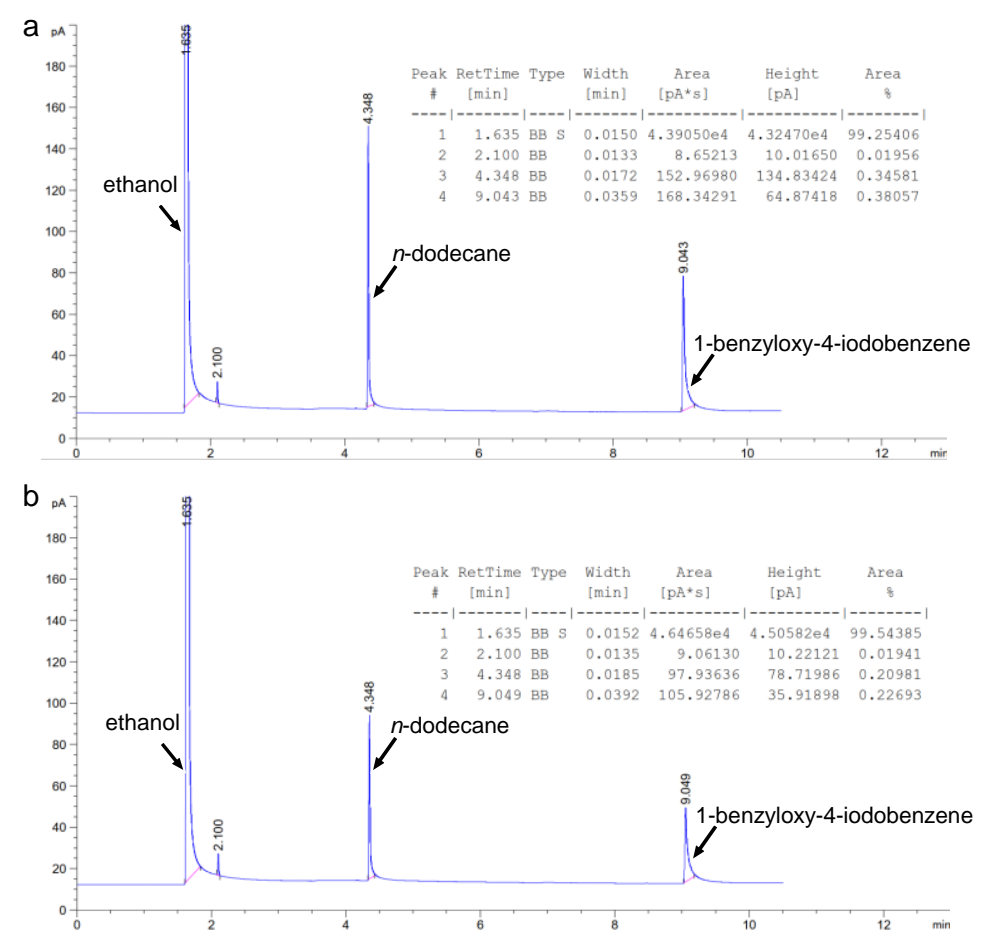

Figure S26. GC chromatograms of Suzuki coupling reaction between 1-benzyloxy-4-iodobenzene and 4-benzyloxyphenylboronic acid using $\mathrm{Pd} / \mathrm{FeO}_{\mathrm{x}} @ \mathrm{SiO}_{2}-600$ as catalyst: (a) before reaction (at time $=0$ ), and (b) after reaction (60 min). Reaction conditions: $0.5 \mathrm{mmol}$ of 1-benzyloxy-4iodobenzene, $1 \mathrm{mmol}$ of 4-benzyloxyphenylboronic acid, $0.1 \mathrm{~mL}$ of $n$-dodecane (as an internal standard for $\mathrm{GC}$ ), $2 \mathrm{mmol}$ of $\mathrm{K}_{2} \mathrm{CO}_{3}, 60 \mathrm{~min}$ at $85^{\circ} \mathrm{C}$. GC operating conditions: inlet temperature at $250{ }^{\circ} \mathrm{C}$, FID temperature at $280^{\circ} \mathrm{C}$, and oven at $70-280{ }^{\circ} \mathrm{C}$ with the ramp rate of $20^{\circ} \mathrm{C} / \mathrm{min}$.

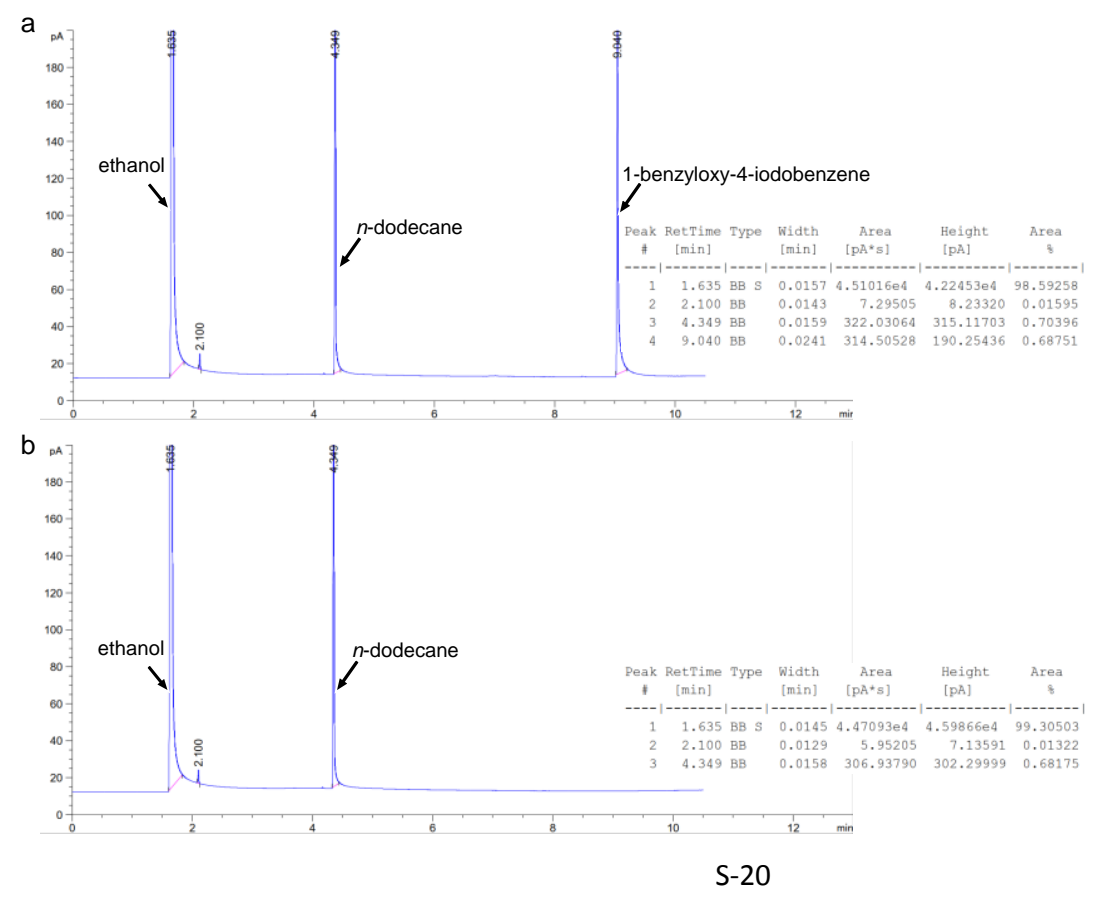


Figure S27. GC chromatograms of Suzuki coupling reaction between 1-benzyloxy-4-iodobenzene and 4-benzyloxyphenylboronic acid using $\mathrm{Pd} / \mathrm{C}$ as catalyst: (a) before reaction (at time $=0$ ), and (b) after reaction (60 $\mathrm{min}$ ). Reaction conditions: $0.5 \mathrm{mmol}$ of 1-benzyloxy-4-iodobenzene, $1 \mathrm{mmol}$ of 4benzyloxyphenylboronic acid, $0.1 \mathrm{~mL}$ of $n$-dodecane (as an internal standard for GC), $2 \mathrm{mmol}$ of $\mathrm{K}_{2} \mathrm{CO}_{3}, 60$ min at $85^{\circ} \mathrm{C}$. GC operating conditions: inlet temperature at $250{ }^{\circ} \mathrm{C}$, FID temperature at $280^{\circ} \mathrm{C}$, and oven at $70-280{ }^{\circ} \mathrm{C}$ with the ramp rate of $20^{\circ} \mathrm{C} / \mathrm{min}$. Due to its high boiling point, the product for this reaction was not detected under our GC setting.
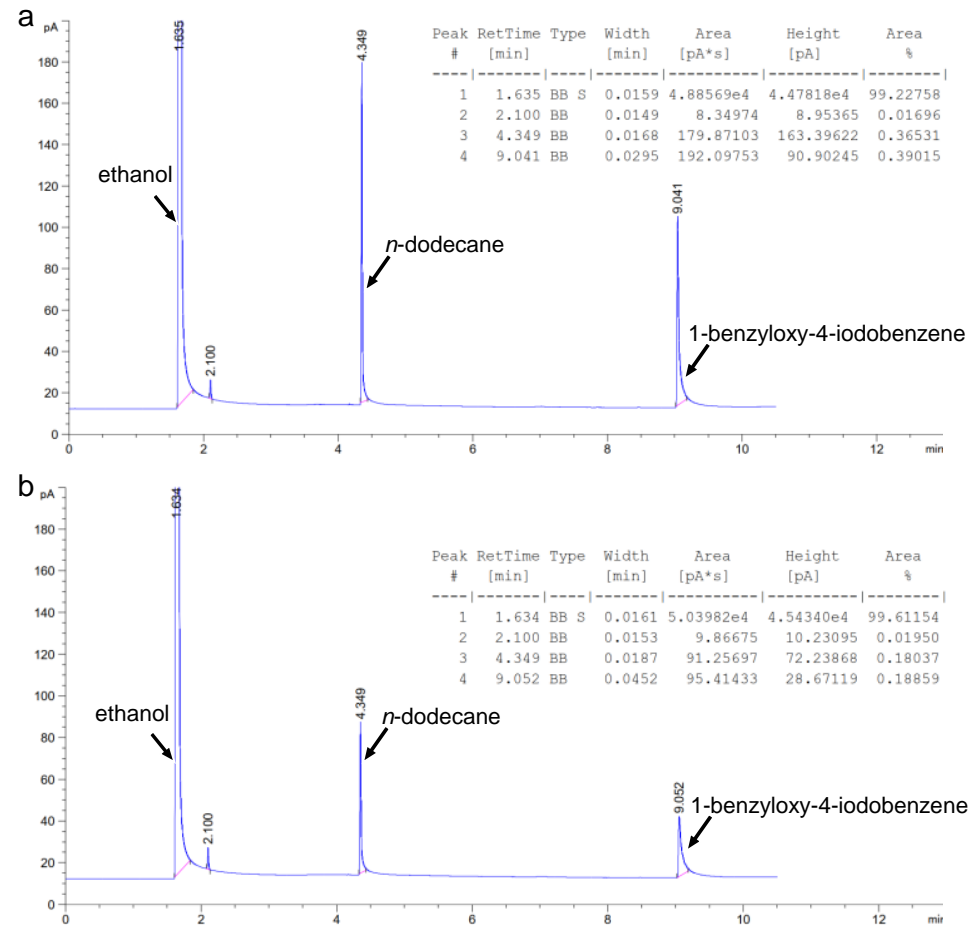

Figure S28. GC chromatograms of Suzuki coupling reaction between 1-benzyloxy-4-iodobenzene and phenylboronic acid using $\mathrm{Pd} / \mathrm{FeO}_{\mathrm{x}} @ \mathrm{SiO}_{2}-600$ as catalyst: (a) before reaction (at time $=0$ ), and (b) after reaction (60 min). Reaction conditions: $0.5 \mathrm{mmol}$ of 1-benzyloxy-4-iodobenzene, $1 \mathrm{mmol}$ of phenylboronic acid, $0.1 \mathrm{~mL}$ of $n$-dodecane (as an internal standard for $\mathrm{GC}$ ), $2 \mathrm{mmol}$ of $\mathrm{K}_{2} \mathrm{CO}_{3}, 60$ min at $85^{\circ} \mathrm{C}$. GC operating conditions: inlet temperature at $250{ }^{\circ} \mathrm{C}$, FID temperature at $280^{\circ} \mathrm{C}$, and oven at $70-280{ }^{\circ} \mathrm{C}$ with the ramp rate of $20^{\circ} \mathrm{C} / \mathrm{min}$. 


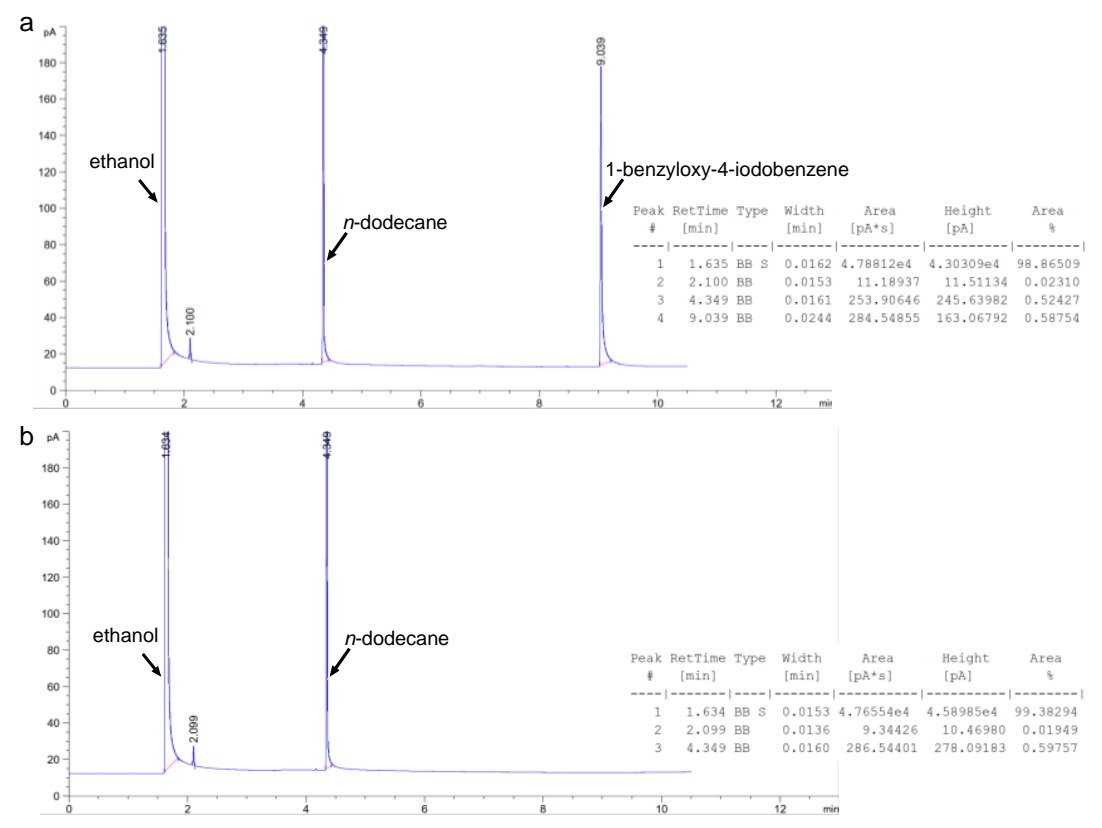

Figure S29. GC chromatograms of Suzuki coupling reaction between 1-benzyloxy-4-iodobenzene and phenylboronic acid using $\mathrm{Pd} / \mathrm{C}$ as catalyst: (a) before reaction (at time $=0$ ), and (b) after reaction (60 $\mathrm{min}$ ). Reaction conditions: $0.5 \mathrm{mmol}$ of 1-benzyloxy-4-iodobenzene, $1 \mathrm{mmol}$ of phenylboronic acid, $0.1 \mathrm{~mL}$ of $n$-dodecane (as an internal standard for GC), $2 \mathrm{mmol}$ of $\mathrm{K}_{2} \mathrm{CO}_{3}, 60 \mathrm{~min}$ at $85^{\circ} \mathrm{C}$. GC operating conditions: inlet temperature at $250{ }^{\circ} \mathrm{C}$, FID temperature at $280^{\circ} \mathrm{C}$, and oven at $70-280{ }^{\circ} \mathrm{C}$ with the ramp rate of $20^{\circ} \mathrm{C} / \mathrm{min}$. Due to its high boiling point, the product for this reaction was not detected under our GC setting.

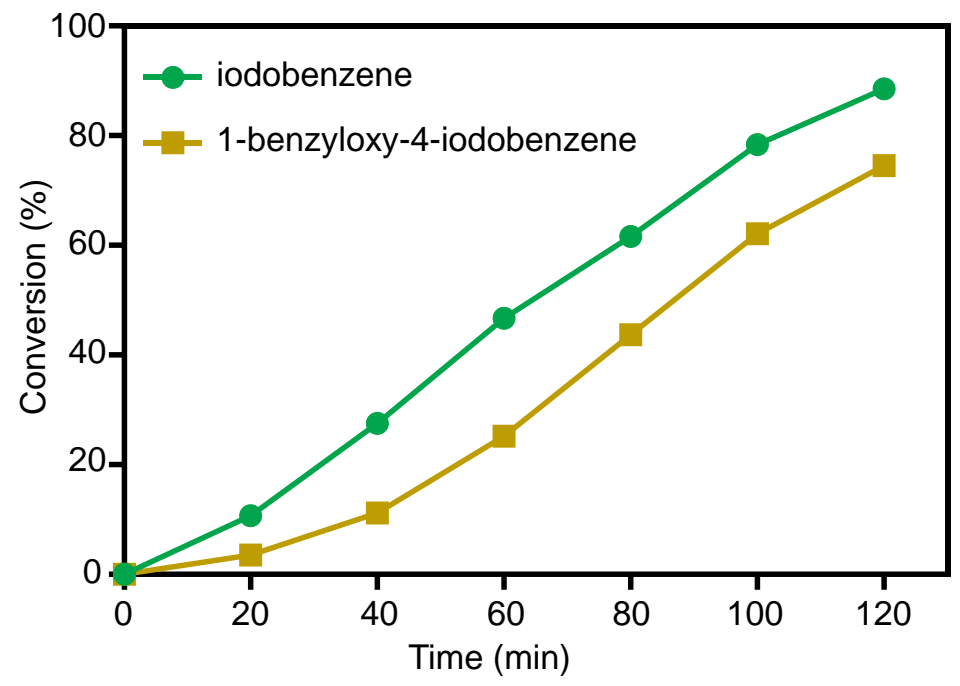

Figure S30. Catalytic performances of Suzuki-Miyaura cross-coupling reactions between iodobenzene and phenylboronic acid (green curve) and 1-benzyloxy-4-iodobenzene and phenylboronic acid (golden yellow curve) over $\mathrm{Pd} / \mathrm{FeO}_{\mathrm{x}} @ \mathrm{SiO}_{2}-600$. Reaction conditions: iodobenzene $(0.5 \mathrm{mmol}), 1$-benzyloxy-4-iodobenzene $(0.5 \mathrm{mmol})$, phenylboronic acid $(1.5 \mathrm{mmol})$, $\mathrm{K}_{2} \mathrm{CO}_{3}(2 \mathrm{mmol})$, and ethanol $(10 \mathrm{~mL})$; reaction temperature at $85^{\circ} \mathrm{C}$ under atmospheric condition. 

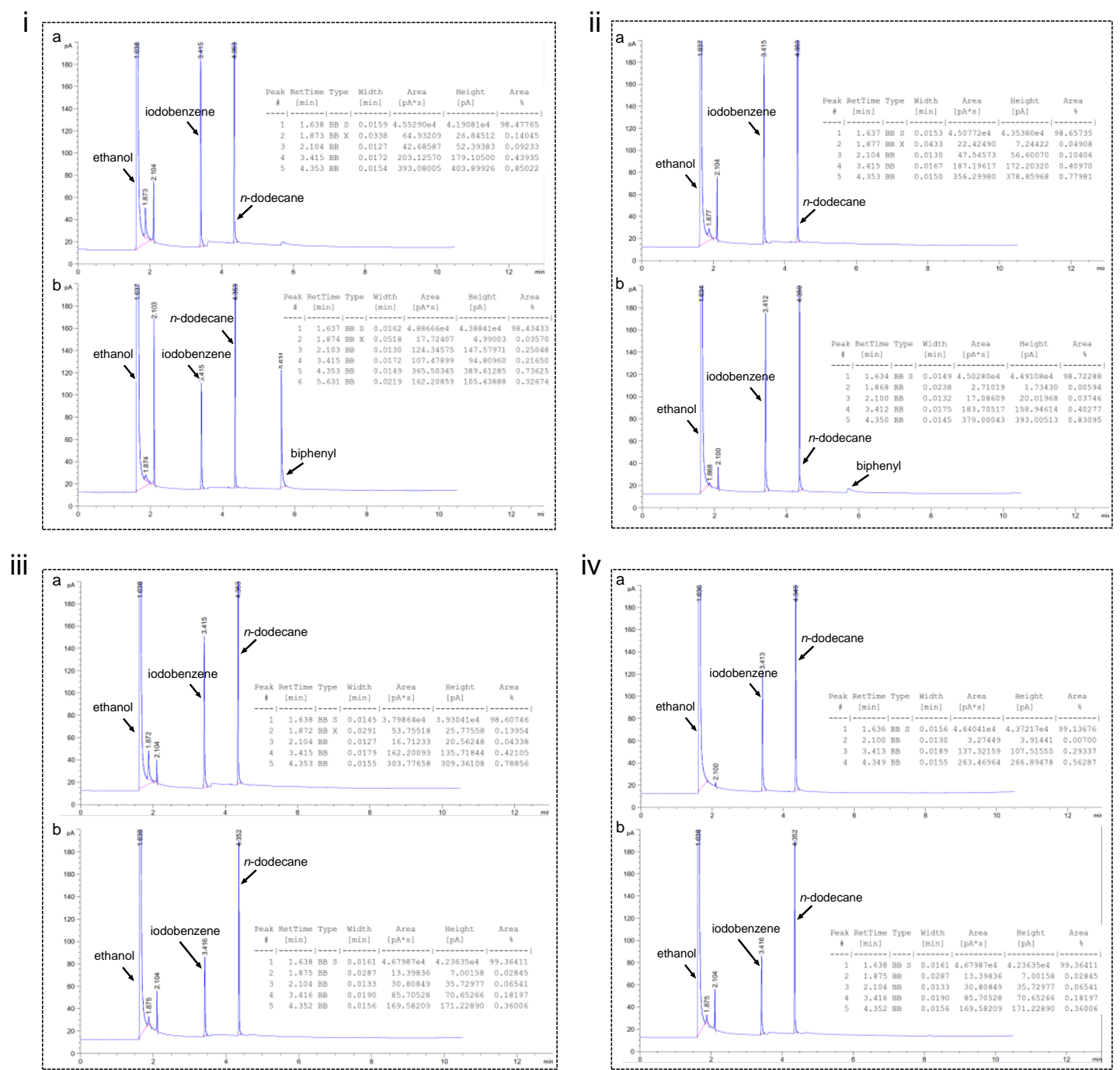

Figure S31. GC chromatograms of recycle tests of $\mathrm{Pd} / \mathrm{FeO}_{\mathrm{x}} @ \mathrm{SiO}_{2}-600$ in the reaction between iodobenzene and phenylboronic acid: (i) 1 time, (ii) 2 times, (iii) 3 times, and (iv) 4 times; (a) before reaction (at time $=0$ ), and (b) after reaction (50 $\mathrm{min}$ ). Reaction conditions: $0.5 \mathrm{mmol}$ of iodobenzene, $1 \mathrm{mmol}$ of phenylboronic acid, $0.1 \mathrm{~mL}$ of $n$-dodecane (as an internal standard for GC), $2 \mathrm{mmol}$ of $\mathrm{K}_{2} \mathrm{CO}_{3}, 85^{\circ} \mathrm{C}$; refer to Figure $3 \mathrm{c}$ in the main text for further information on the reaction. Reaction time was set at 50 min in each recycle experiment. GC operating conditions: inlet temperature at $250^{\circ} \mathrm{C}$, FID temperature at $280^{\circ} \mathrm{C}$, and oven at $70-280{ }^{\circ} \mathrm{C}$ with the ramp rate of $20^{\circ} \mathrm{C} / \mathrm{min}$. 

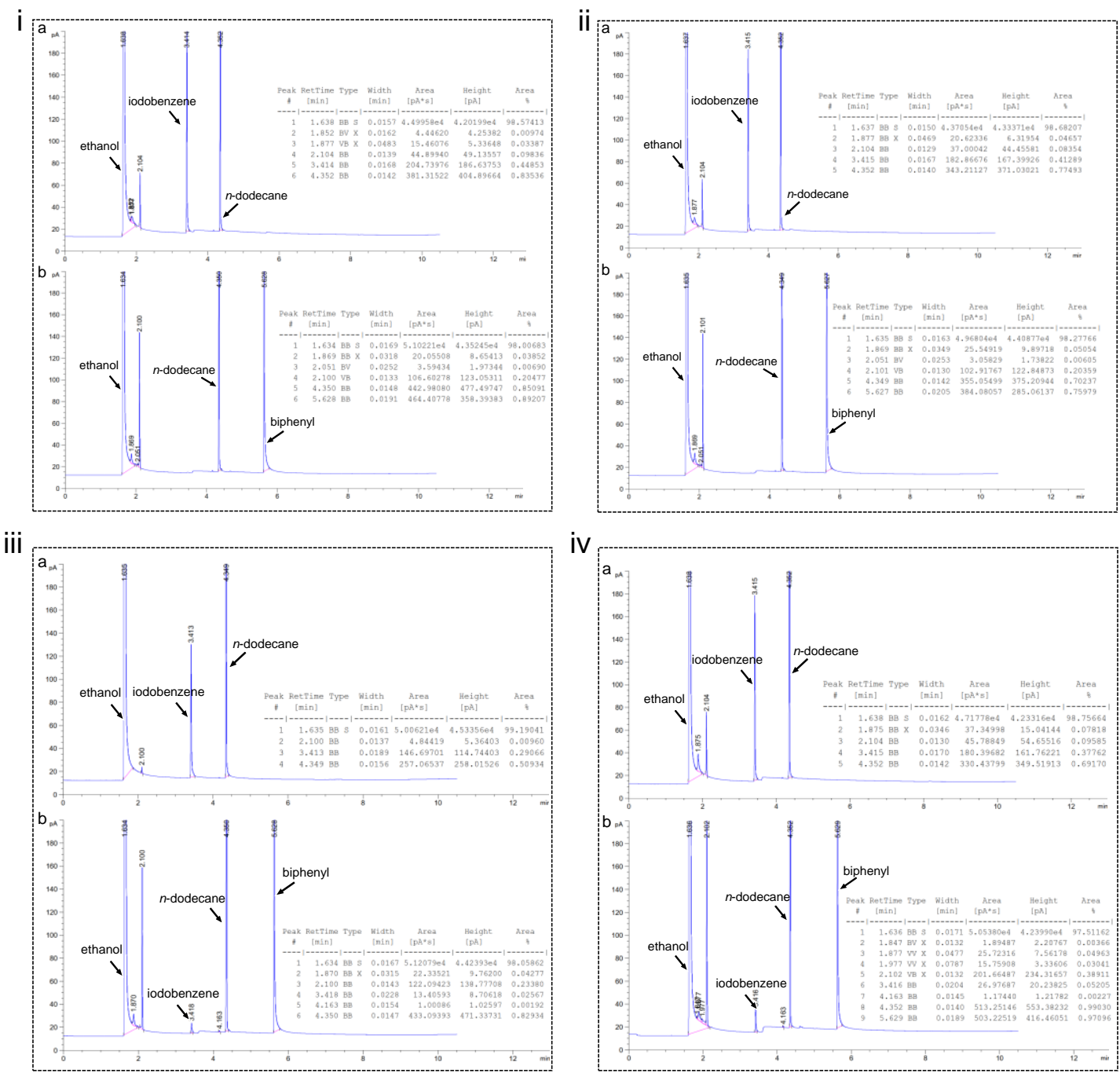

Figure S32. GC chromatograms of recycle tests of $\mathrm{Pd} / \mathrm{FeO}_{\mathrm{x}} @ \mathrm{SiO}_{2}-600$ in the reaction between iodobenzene and phenylboronic acid: (i) 1 time, (ii) 2 times, (iii) 3 times, and (iv) 4 times; (a) before reaction (at time $=0$ ), and (b) after reaction $(120 \mathrm{~min}$ ). Reaction conditions: $0.5 \mathrm{mmol}$ of iodobenzene, $1 \mathrm{mmol}$ of phenylboronic acid, $0.1 \mathrm{~mL}$ of $n$-dodecane (as an internal standard for GC), $2 \mathrm{mmol}$ of $\mathrm{K}_{2} \mathrm{CO}_{3}, 85^{\circ} \mathrm{C}$; refer to Figure $3 \mathrm{~d}$ in the main text for further information on the reaction. Reaction time was set at $120 \mathrm{~min}$ in each recycle experiment. GC operating conditions: inlet temperature at $250^{\circ} \mathrm{C}$, FID temperature at $280^{\circ} \mathrm{C}$, and oven at $70-280{ }^{\circ} \mathrm{C}$ with the ramp rate of $20^{\circ} \mathrm{C} / \mathrm{min}$. 

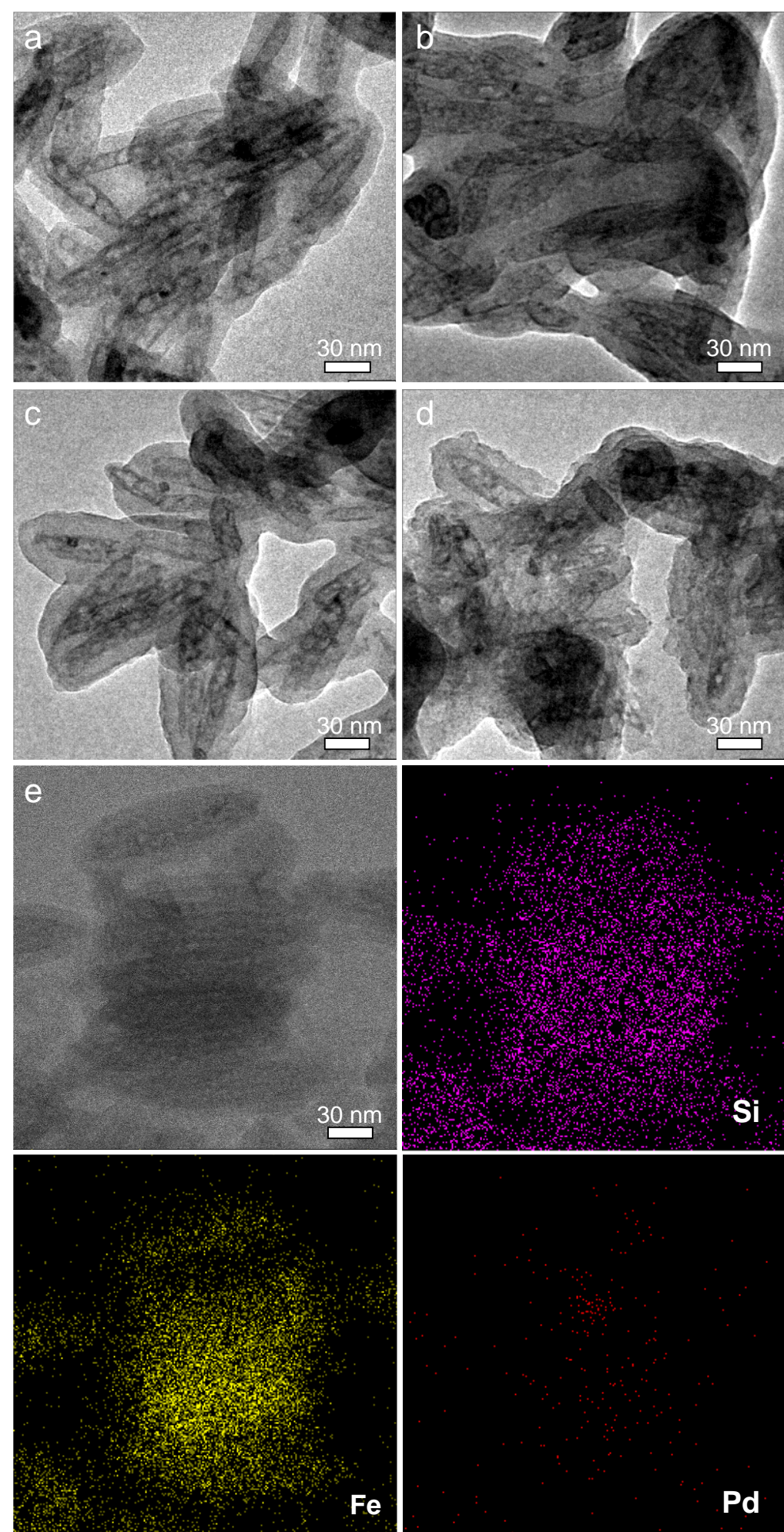

Figure S33. TEM images of $\mathrm{Pd} / \mathrm{FeO}_{\mathrm{x}} @ \mathrm{SiO}_{2}-600$ after it was recycled for: (a) 1 time, (b) 2 times, (c) 3 times, and (d) 4 times; and (e) EDX elemental mapping images of $\mathrm{Pd} / \mathrm{FeO}_{\mathrm{x}} @ \mathrm{SiO}_{2}-600$ after recycled for 4 times; refer to Figure $3 \mathrm{c}$ in the main text for further information on the reaction. Reaction time was set at $50 \mathrm{~min}$ in each recycle experiment (also see Figure $3 \mathrm{c}$ in the main text). 

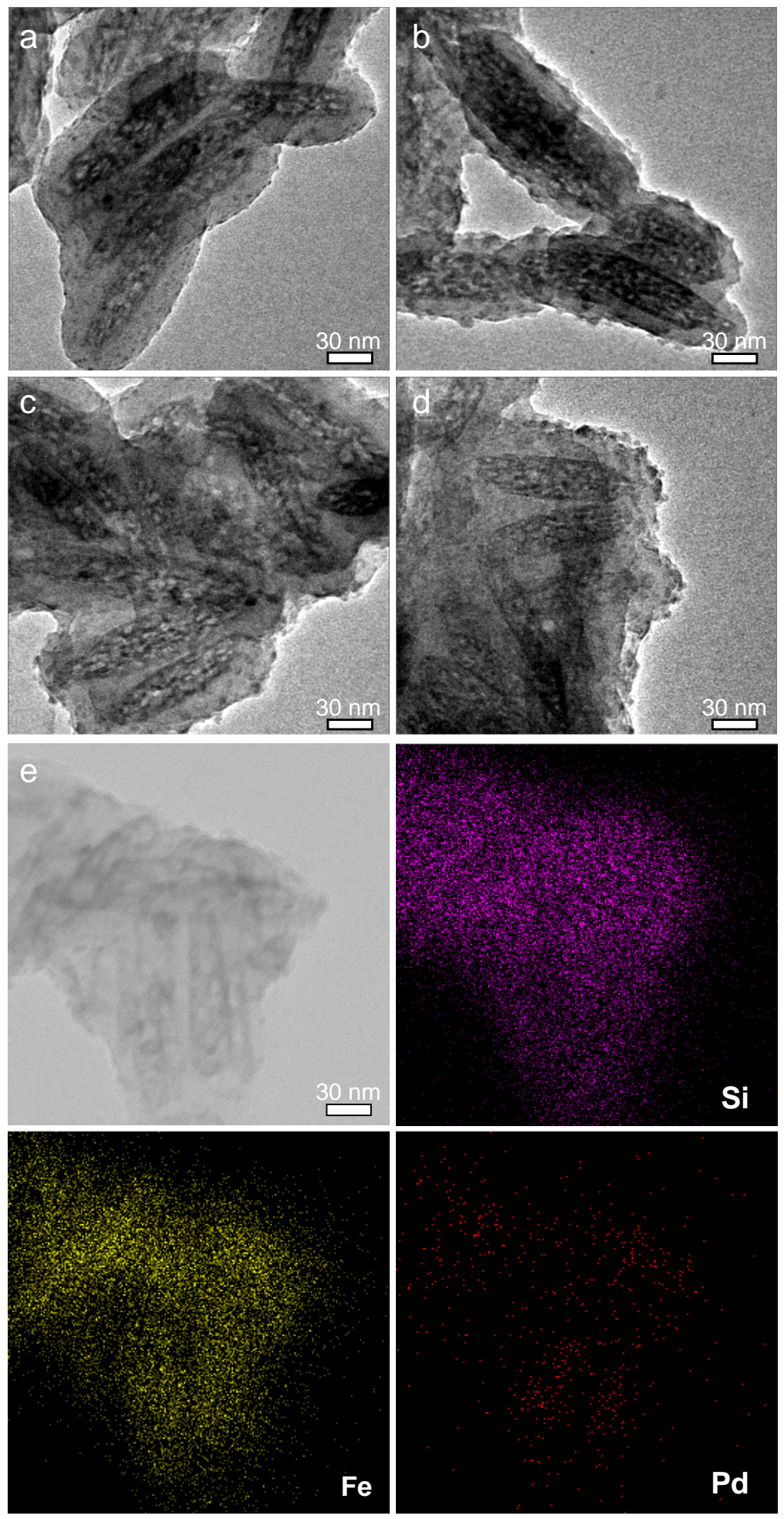

Figure S34. TEM images of $\mathrm{Pd} / \mathrm{FeO}_{\mathrm{x}} @ \mathrm{SiO}_{2}-600$ after it was recycled for: (a) 1 time, (b) 2 times, (c) 3 times, and (d) 4 times; and (e) EDX elemental mapping images of $\mathrm{Pd} / \mathrm{FeO} \mathrm{O}_{\mathrm{x}} @ \mathrm{SiO}_{2}-600$ after recycled for 4 times; refer to Figure $3 \mathrm{~d}$ in the main text for further information on the reaction. Reaction time was set at 120 min in each recycle experiment (also see Figure 3d in the main text). 


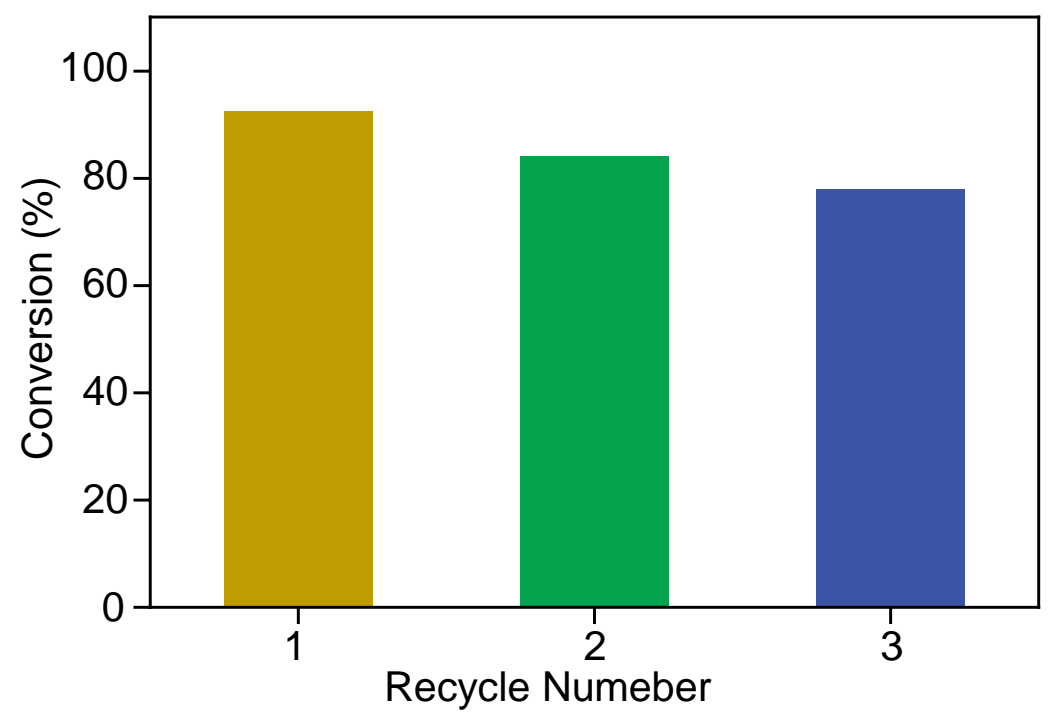

Figure S35. Recycle test of the leaching solution in the reaction between iodobenzene and phenylboronic acid. Reaction conditions: iodobenzene $(0.5 \mathrm{mmol})$, phenylboronic acid $(1.0 \mathrm{mmol})$, $\mathrm{K}_{2} \mathrm{CO}_{3}(2 \mathrm{mmol})$, ethanol $(\sim 10 \mathrm{~mL})$; reaction temperature at $85^{\circ} \mathrm{C}$ under atmospheric conditions. Each experimental run (recycle number 1, 2, and 3) was stopped after 120 min of the reaction.

Detailed reaction process and comments: After reaction for $50 \mathrm{~min}$ between iodobenzene and phenylboronic acid, the mixture was centrifuged at $10000 \mathrm{rpm}$ for $10 \mathrm{~min}$ (similar to the procedure of the first experimental run of Figure $3 c$ in the main text). The clear upper liquid was carefully filtered through a membrane filter into a $25 \mathrm{~mL}$ round-bottom flask. This liquid is named as "the leaching solution" for the three recycle experiments reported above, in which iodobenzene ( 0.5 $\mathrm{mmol})$, phenylboronic acid $(1.0 \mathrm{mmol})$, and $\mathrm{K}_{2} \mathrm{CO}_{3}(2 \mathrm{mmol})$ were added to the leaching solution from the previous one; each reaction run was stopped after $120 \mathrm{~min}$ of the reaction. 


\section{Supporting Tables:}

Table S1. The dimensions of several molecules estimated by our method compared to experimental results.

\begin{tabular}{lllllll}
\hline Molecule & Urea & Gly & Glycol & Glycerol & Acetamide & Formamide \\
\hline Results & $3.4 \times 5.0 \times 5.5$ & $3.4 \times 5.1 \times 6.8$ & $4.0 \times 4.4 \times 6.0$ & $4.0 \times 5.3 \times 7.9$ & $3.4 \times 5.3 \times 5.6$ & $3.4 \times 4.0 \times 5.3$ \\
& $\AA^{3}$ & $\AA^{3}$ & $\AA^{3}$ & $\AA^{3}$ & $\AA^{3}$ & $\AA^{3}$ \\
Benchmark & $3.6 \times 5.2 \times 5.4$ & $3.7 \times 5.1 \times 7.1$ & $3.7 \times 4.7 \times 6.3$ & $4.8 \times 5.1 \times 7.8$ & $3.8 \times 5.2 \times 5.4$ & $3.4 \times 4.4 \times 5.4$ \\
& $\AA^{3}$ & $\AA^{3}$ & $\AA^{3}$ & $\AA^{3}$ & $\AA^{3}$ & $\AA^{3}$ \\
\hline
\end{tabular}

Table S2. Structural property of the sample $\mathrm{Pd} / \beta-\mathrm{FeOOH} @ \mathrm{SiO}_{2}$ and $\mathrm{Pd} / \mathrm{FeO}_{\mathrm{x}} @ \mathrm{SiO}_{2}$ after calcined at different temperatures.

\begin{tabular}{l|l|l|l|l|l}
\hline Sample & $\mathrm{Pd} / \beta-\mathrm{FeOOH} @ \mathrm{SiO}_{2}$ & $\mathrm{Pd} / \mathrm{FeO}_{\mathrm{x}} @ \mathrm{SiO}_{2}-500$ & $\mathrm{Pd} / \mathrm{FeO}_{\mathrm{x}} @ \mathrm{SiO}_{2}-600$ & $\mathrm{Pd} / \mathrm{FeO}_{\mathrm{x}} @ \mathrm{SiO}_{2}-700$ & $\mathrm{Pd} / \mathrm{FeO}_{\mathrm{x}} @ \mathrm{SiO}_{2}-800$ \\
\hline $\begin{array}{l}\text { BET surface area } \\
\left(\mathrm{m}^{2} \mathrm{~g}^{-1}\right)\end{array}$ & 442.1 & 280.6 & 183.1 & 79.1 & 46.3 \\
$\begin{array}{l}\text { Pore volume } \\
\left(\mathrm{cm}^{3} \mathrm{~g}^{-1}\right)\end{array}$ & 0.208 & 0.138 & 0.083 & 0.022 & 0.014 \\
\hline
\end{tabular}

Table S3. Dimensions of reactants and products.

\begin{tabular}{l|l|l|l}
\hline Reactants & Dimensions & Product & Dimensions \\
\hline cyclohexene & $6.3 \times 5.7 \times 4.5 \AA^{3}$ & cyclohexane & $6.2 \times 6.2 \times 3.9 \AA^{3}$ \\
styrene & $8.5 \times 6.0 \times 4.0 \AA^{3}$ & ethylbenzene & $8.5 \times 6.1 \times 3.6 \AA^{3}$ \\
4-methylstyrene & $9.8 \times 6.0 \times 3.4 \AA^{3}$ & 4-ethyltoluene & $9.9 \times 6.0 \times 3.4 \AA^{3}$ \\
4-vinylbiphenyl & $12.0 \times 5.7 \times 3.4 \AA^{3}$ & 4-ethylbiphenyl & $12.0 \times 5.8 \times 3.4 \AA^{3}$ \\
iodobenzene & $8.5 \times 5.9 \times 4.0 \AA^{3}$ & biphenyl & $10.3 \times 5.8 \times 3.8 \AA^{3}$ \\
phenylboronic acid & $8.4 \times 6.2 \times 3.4 \AA^{3}$ & 4-tert-butylbiphenyl & $12.3 \times 6.0 \times 5.9 \AA^{3}$ \\
4-tert-butylphenylboronic acid & $10.8 \times 6.0 \times 5.8 \AA^{3}$ & & \\
4-benzyloxyphenylboronic acid & $14.8 \times 6.3 \times 3.0 \AA^{3}$ & & \\
1-benzyloxy-4-iodobenzene & $14.8 \times 5.8 \times 3.0 \AA^{3}$ & & \\
\hline
\end{tabular}


Table S4. Summary of Pd content in leaching solution based on ICP-MS analysis.

\begin{tabular}{|l|l|}
\hline Sample & Pd content $(\mathrm{ppb})$ in solution \\
\hline $\mathrm{Pd} / \mathrm{FeO}_{\mathrm{x}} @ \mathrm{SiO}_{2}-600^{\mathrm{a}}$ & 141 \\
$\mathrm{Pd} / \mathrm{FeO}_{\mathrm{x}} @ \mathrm{SiO}_{2}-600^{\mathrm{b}}$ & 27 \\
\hline
\end{tabular}

Notes: (a) After reaction for $50 \mathrm{~min}$ in Suzuki coupling reaction between iodobenzene and phenylboronic acid (equivalent to the first run of Figure $3 \mathrm{c}$ in the main text), and (b) after reaction for $120 \mathrm{~min}$ in Suzuki coupling reaction between iodobenzene and phenylboronic acid (equivalent to the first run of Figure $3 d$ in the main text).

Comments: After reaction, the mixture was centrifuged at $10000 \mathrm{rpm}$ for $10 \mathrm{~min}$. The clear upper layer was carefully filtered through a membrane filter. After evaporation of the solvent, the sample was treated with aqua regia and analyzed by ICP-MS.

Table S5. Summary of Pd contents (based on ICP-OES analysis) in fresh $\mathrm{Pd} / \mathrm{FeO}_{\mathrm{x}} @ \mathrm{SiO}_{2}-600$ and in spent catalyst $\mathrm{Pd} / \mathrm{FeO}_{\mathrm{x}} @ \mathrm{SiO}_{2}-600$ with different reaction times.

\begin{tabular}{|l|l|}
\hline Sample & Pd content $(\mathrm{wt} \%)$ in sample \\
\hline Fresh $\mathrm{Pd} / \mathrm{FeO}{ }_{\mathrm{x}} @ \mathrm{SiO}_{2}-600$ & 0.85 \\
$\mathrm{Spent} \mathrm{Pd} / \mathrm{FeO}_{\mathrm{x}} @ \mathrm{SiO}_{2}-600^{\mathrm{a}}$ & 0.76 \\
Spent $\mathrm{Pd} / \mathrm{FeO}_{\mathrm{x}} @ \mathrm{SiO}_{2}-600^{\mathrm{b}}$ & 0.82 \\
\hline
\end{tabular}

Notes: (a) After reaction for 50 min in Suzuki coupling reaction between iodobenzene and phenylboronic acid (equivalent to the first run of Figure $3 \mathrm{c}$ in the main text), and (b) after reaction for $120 \mathrm{~min}$ in Suzuki coupling reaction between iodobenzene and phenylboronic acid (equivalent to the first run of Figure 3d in the main text). 


\section{Calculated Molecular Dimensions:}

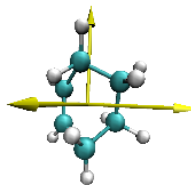

cyclohexene

$6.3 \times 5.7 \times 4.5 \AA^{3}$<smiles>C1=CCCCC1</smiles>

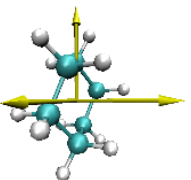

cyclohexane

$6.2 \times 6.2 \times 3.9 \AA^{3}$<smiles>C1CCCCC1</smiles>

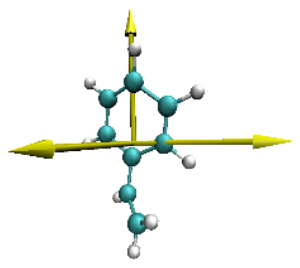

styrene

$8.5 \times 6.0 \times 4.0 \AA^{3}$<smiles>C=Cc1ccccc1</smiles>

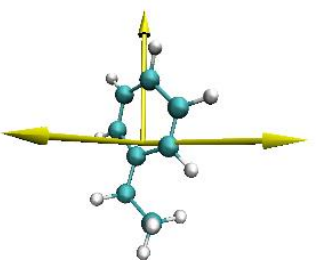

ethylbenzene

$8.5 \times 6.1 \times 3.6 \AA^{3}$<smiles>CCCc1ccccc1</smiles>

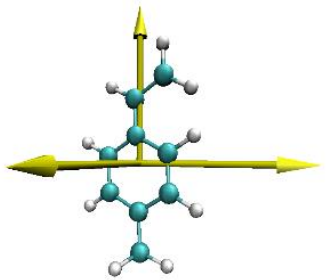

4-methylstyrene

$9.8 \times 6.0 \times 3.4 \AA^{3}$<smiles>C=Cc1ccc(C)cc1</smiles>

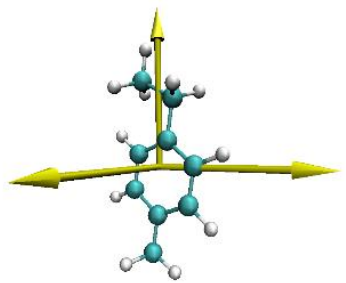

4-ethyltoluene

$9.9 \times 6.0 \times 3.4 \AA^{3}$<smiles>CCc1ccc(C)cc1</smiles> 

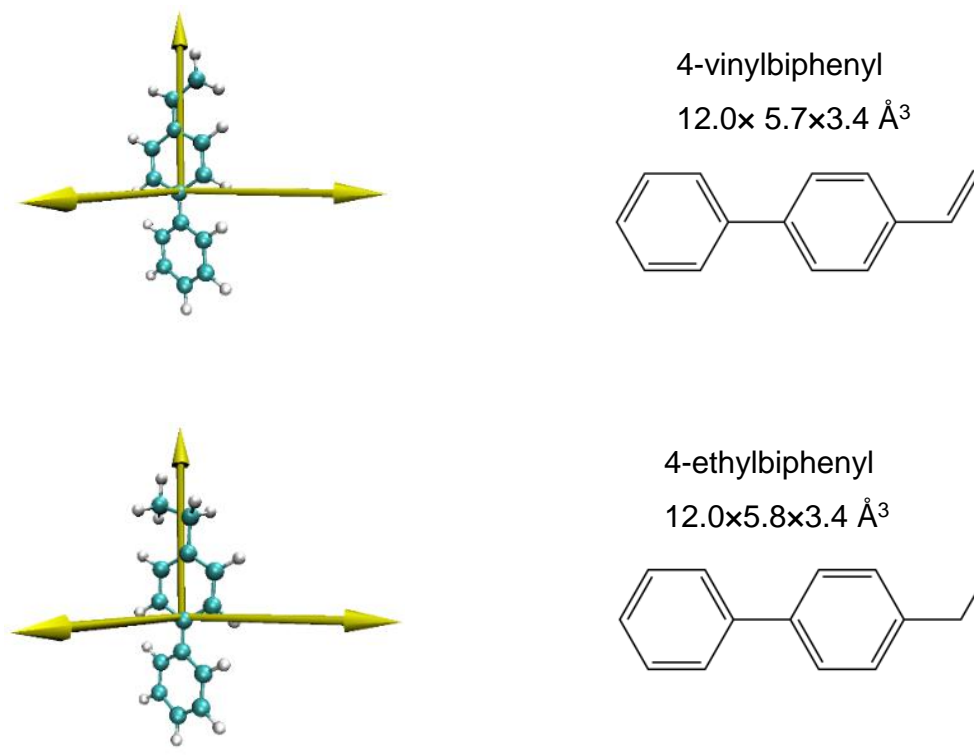

\section{4-ethylbiphenyl}

$12.0 \times 5.8 \times 3.4 \AA^{3}$
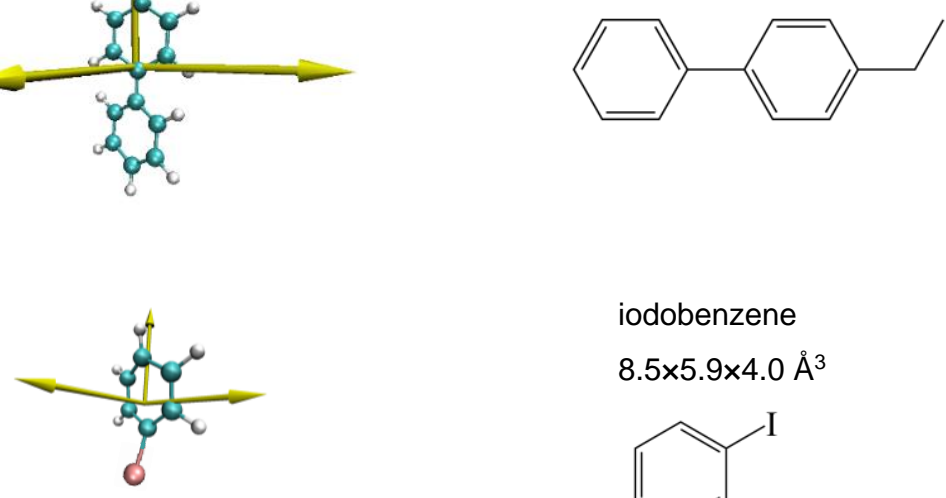

iodobenzene

$8.5 \times 5.9 \times 4.0 \AA^{3}$<smiles>Ic1ccccc1</smiles>

1-benzyloxy-4-iodobenzene

$14.8 \times 5.8 \times 3.0 \AA^{3}$
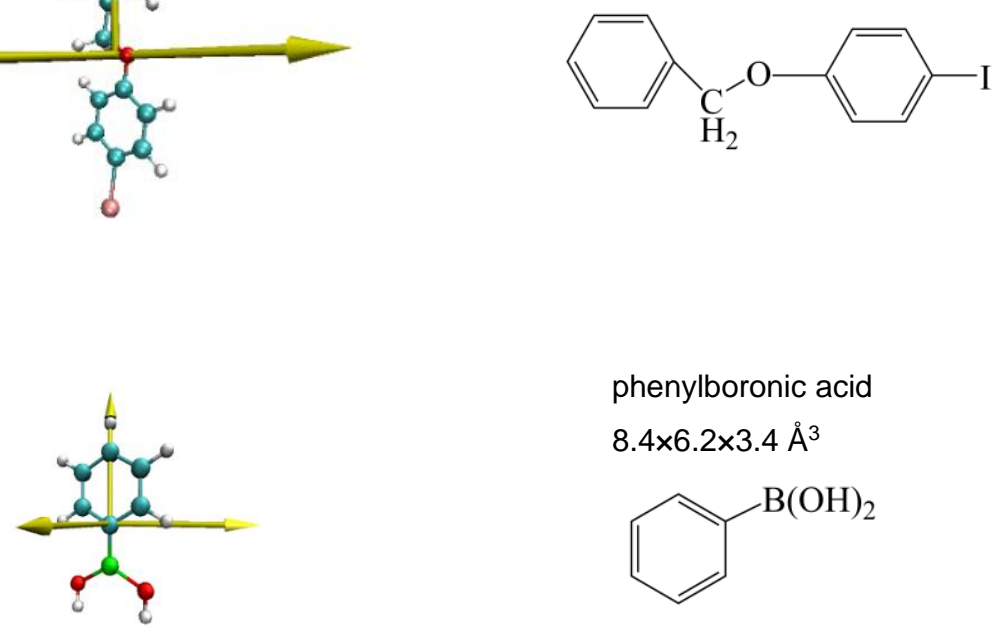

phenylboronic acid

$8.4 \times 6.2 \times 3.4 \AA^{3}$<smiles>Oc1ccccc1</smiles> 

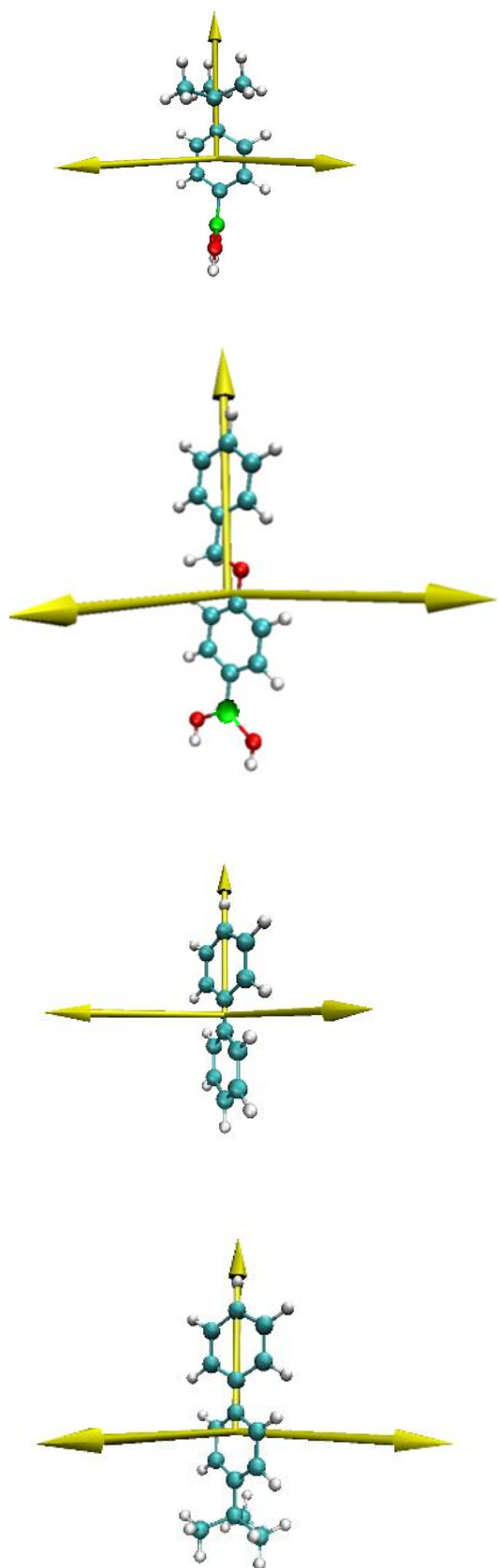

4-tert-butylphenylboronic acid $10.8 \times 6.0 \times 5.8 \AA^{3}$

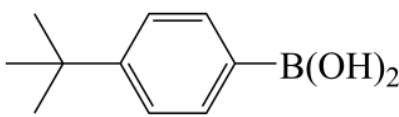

4-benzyloxyphenylboronic acid $14.8 \times 6.3 \times 3.0 \AA^{3}$<smiles>Oc1ccc(OCc2ccccc2)cc1</smiles>

biphenyl

$10.3 \times 5.8 \times 3.8 \AA^{3}$

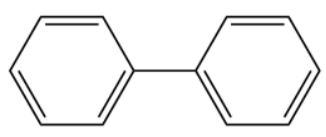

4-tert-butylbiphenyl

$12.3 \times 6.0 \times 5.9 \AA^{3}$

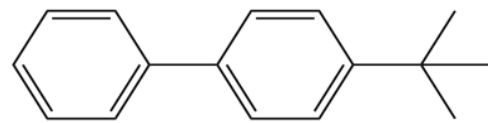

